\title{
WestVirginiaUniversity
}

THE RESEARCH REPOSITORY @ WVU

Graduate Theses, Dissertations, and Problem Reports

2000

\section{Parental influences on high school student achievement and goals}

Richard K. York

West Virginia University

Follow this and additional works at: https://researchrepository.wvu.edu/etd

\section{Recommended Citation}

York, Richard K., "Parental influences on high school student achievement and goals" (2000). Graduate Theses, Dissertations, and Problem Reports. 1117.

https://researchrepository.wvu.edu/etd/1117

This Thesis is protected by copyright and/or related rights. It has been brought to you by the The Research Repository @ WVU with permission from the rights-holder(s). You are free to use this Thesis in any way that is permitted by the copyright and related rights legislation that applies to your use. For other uses you must obtain permission from the rights-holder(s) directly, unless additional rights are indicated by a Creative Commons license in the record and/ or on the work itself. This Thesis has been accepted for inclusion in WVU Graduate Theses, Dissertations, and Problem Reports collection by an authorized administrator of The Research Repository @ WVU. For more information, please contact researchrepository@mail.wvu.edu. 


\title{
PARENTAL INFLUENCES \\ ON HIGH SCHOOL STUDENT ACHIEVEMENT AND GOALS
}

Richard K. York

\author{
A thesis submitted to the \\ Division of Family and Consumer Sciences \\ College of Agriculture and Forestry \\ at West Virginia University \\ in partial fulfillment of the requirements \\ for the degree of \\ Master of Science \\ In \\ Child Development/Family Studies \\ Carol Markstrom, Ph.D., Chair \\ Bobbie Warash, Ed.D. \\ Wanda Franz, Ph.D. \\ Morgantown, West Virginia \\ 2000
}

Keywords: Adolescence, Parental Influences, Career 


\section{Abstract \\ Parental Influences on High School Student Achievement and Goals}

\section{Richard K. York}

The present study examined parental influences on educational and career goals of high school students. Data on educational and career goals from the Perceived Life Chances Interview were derived from 124 rural adolescents. One hundred of their mothers and 36 of their fathers completed the Inventory of Parental Influence which consists of five subscales of Parental Involvement/Help, Psychological Support, Parental Pressure, Pressure for Intellectual Development, and Time Management/Monitoring. Responses from the Perceived Life Chances Interview were qualitatively analyzed in order to derive categories that reflected the varying responses from participants. These categories served as dependent variables in a series of discriminant function and regression analyses that included the five subscales of the Inventory of Parental Influence, race, and gender as the predictor variables. It was evident from present and prior research that parental influences were found to be associated with adolescent achievement and career goals. 


\section{Acknowledgments}

I would like to express my sincere gratitude and thanks to the following people who helped me to achieve the goal of receiving a Master's degree:

My committee chairperson, Dr. Carol Markstrom, for your constant guidance and support. Thank you for your support over the past two years. You have been an outstanding mentor and friend.

My committee members, Dr. Wanda Franz, and Dr. Bobbie Warash, for your many words of encouragement and feedback.

My colleagues, Mickey, Trey, Kathy, and Janie, who provided me with many words of encouragement and support. Thank you for the past two years. A special thanks to Kathy for her outstanding "Power Point skills".

My entire family, for your belief in me and support no matter what.

Most of all, thanks to my wife Teresa and daughter Jessica, who give me daily inspiration and desire to succeed. Your unconditional support means everything. Thank you for everything! 
Table of Contents

Page

Acknowledgements...................................................................................................iii

Table of Contents .......................................................................................... iv

List of Tables ..................................................................................................... vi

Chapter

I Introduction ......................................................................................... 1

Overview ........................................................................................ 1

Justification ................................................................................. 1

Statement of the Problem ................................................... 2

Statement of the Purpose ............................................................ 3

Terminology ............................................................................4

Summary ........................................................................................5

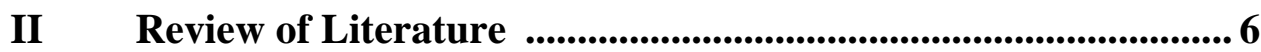

Overview ..........................................................................

Bronfenbrenner's Ecological Model .................................. 7

Parental Influences on Achievement and Goals .............9

Parental Involvement/Help...................................... 10

Psychological Support ................................................. 17

Parental Influences/Pressure ................................ 19

Pressure for Intellectual Development ...............21

Monitoring/Time Management .............................22

Summary ............................................................................................ 24

Hypothesis/Predictions ............................................................................. 25

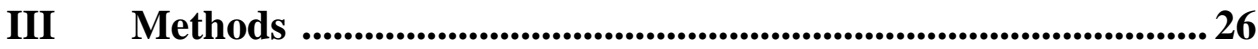

Overview .................................................................................. 26

Sample Section ......................................................................... 27

Locating Rural Areas ................................................ 27

Selection of Schools ................................................... 27

Screening Procedure ................................................... 28

Final Sample ............................................................. 28

Data Collection Procedures .................................................. 29

Instruments ........................................................................30

Perceived Life Chances Interview ....................... 30

Inventory of Parental Influence ............................ 31

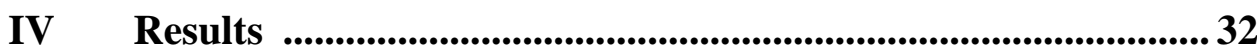

Overview of Statistical Analysis......................................... 32

Reliability of Inventory of Parental Influence................ 33

Qualitative Analysis ..................................................................34 
Quantitative Analysis...........................................................36

Significant Variables for Maternal Data............ 43

Significant Variables for Paternal Data................49

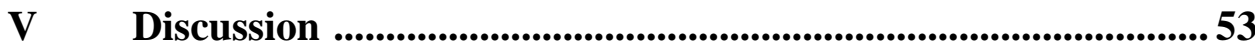

Overview of Study .................................................................5 53

Parental Pressure .......................................................53

Psychological Support..............................................55

Parental Help ...............................................................55

Pressure for Intellectual Development .................56

Monitoring/Time Management ..............................57

Results of Parental Subscales ..............................55

Gender and Race .......................................................58

Limitations ......................................................................... 61

Contributions.............................................................61 61

Future Research ........................................................62 62

Summary ....................................................................... 63

References ................................................................................................................. 65

Appendices

Appendix A: Adolescent Background Information .................... 70

Appendix B: Parental Background Information......................... 72

Appendix C: Adolescent Assent Form ............................................ 74

Appendix D: Adolescent Consent Form.......................................... 76

Appendix E: Home-Visit Checklist................................................ 79

Appendix F: Parental Consent Form ............................................ 81

Appendix G: Perceived Life Chances Interview ......................... 84

Appendix H: Inventory of Parental Influence

Form for Mother and Father ................................ 87

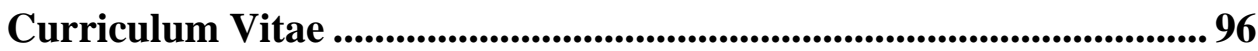




\begin{tabular}{|c|c|c|}
\hline Table & Title & Page \\
\hline Table 1 & $\begin{array}{l}\text { Cronbach's Alphas of all Maternal and Paternal Measures of } \\
\text { the Inventory of Parental Influence }\end{array}$ & 33 \\
\hline Table 2 & $\begin{array}{l}\text { Categories and Inter-Rater Reliability established for } \\
\text { Dependent Variables }\end{array}$ & 35 \\
\hline Table 3 & $\begin{array}{l}\text { Eigenvalues, Wilk's Lambdas, Canonical Correlations, } \\
\text { Chi-Square Values, and Classification Results for Discriminant } \\
\text { Functions for Maternal Data }\end{array}$ & 37 \\
\hline Table 4 & $\begin{array}{l}\text { Eigenvalues, Wilk's Lambdas, Canonical Correlations, } \\
\text { Chi-Square Values, and Classification Results for Discriminant } \\
\text { Functions for Paternal Data }\end{array}$ & 40 \\
\hline Table 5 & $\begin{array}{l}\text { Summary of Significant Multiple Regression Analyses for } \\
\text { Continuous Dependent Variable (SES) for Maternal Data } \\
(\mathrm{N}=100)\end{array}$ & 43 \\
\hline Table 6 & $\begin{array}{l}\text { Means for Adolescents Desired Job when Finished with } \\
\text { Education }(\underline{n}=100)\end{array}$ & 44 \\
\hline Table 7 & $\begin{array}{l}\text { Means for Personal and Environmental Barriers } \\
(\underline{\mathrm{n}}=100)\end{array}$ & 44 \\
\hline Table 8 & $\begin{array}{l}\text { Means for Racism and Sexism Barriers } \\
(\underline{\mathrm{n}}=100)\end{array}$ & 45 \\
\hline Table 9 & $\begin{array}{l}\bar{M} \text { eans for Adolescents Plan to Finish Four Years of College } \\
(\underline{n}=100)\end{array}$ & 46 \\
\hline Table 10 & $\begin{array}{l}\text { Means for Adolescents Academic Barriers } \\
(\underline{\mathrm{n}}=100)\end{array}$ & 47 \\
\hline Table 11 & $\begin{array}{l}\text { Means for Parents who Desired Their Adolescents to Obtain a } \\
\text { Job After High School }(\underline{n}=100)\end{array}$ & 47 \\
\hline Table 12 & $\begin{array}{l}\text { Means for Parents who Preferred Their Adolescent go Directly } \\
\text { into the Service after High School }(\underline{n}=100)\end{array}$ & 48 \\
\hline Table 13 & $\begin{array}{l}\text { Means for Adolescent who Planned on Continuing Schooling } \\
\text { after High School }(\underline{n}=100)\end{array}$ & 49 \\
\hline Table 14 & Means for College After High School $(\underline{n}=35)$ & 50 \\
\hline Table 15 & $\begin{array}{l}\text { Means for Adolescents who intended to Finish High School } \\
(\underline{n}=35)\end{array}$ & 51 \\
\hline Table 16 & $\begin{array}{l}\text { Means for Adolescents Whose Parents wanted them to get } \\
\text { Married after High School }(\underline{n}=35)\end{array}$ & 52 \\
\hline
\end{tabular}




\section{Chapter I}

\section{Introduction}

\section{$\underline{\text { Overview }}$}

Adolescents frequently depend on parents for guidance, particularly about their most important academic and career choices (Damon, 1983). The myths about rebellious adolescents tend to be overemphasized. Most adolescents communicate well with their parents and parents continue to be the main source of advice and support during the adolescent years (Trusty, 1996).

The present study examined the effects of parental influences on high school students' achievement and career goals. More specifically, it was determined if adolescents' achievement and goals were related to parental involvement/help, psychological support, parental pressure, pressure for intellectual development, and time management/monitoring. Bronfenbrenner's ecology theory served as the theoretical base for the present study. His theory states that there is a continuous accommodation throughout life between the individual and his environment. In relation to this study, ecologists believe that the adolescent's achievement and career goals will not only be affected by his internal drives, but also by external influences such as the family.

\section{Justification for the Study}

The education of adolescents and youth is an issue of primary concern in this country, yet the number of adolescents who are at high-risk for academic failure remains a problem. Nationally, the high school completion rate for 18- and 19- year olds was only about 75\% in 1989 (U.S. Department of Education, 1989). The long-term negative consequences that school failure and academic underachievement carry with them for 
occupational and economic outcomes in adulthood are well-documented (DuBois, Eitel \& Felner, 1994). Although the nation acknowledges the importance of families, schools, and children, there seems to be an unwillingness to successfully integrate them. It is very difficult to construct a picture of ideal family interactions that are sure to promote children's success in school (Ryan, Adams, Gullotta, Weissberg, \& Hampton, 1995). Little research has been conducted on at-risk adolescents, especially African Americans, living in rural, economically-deprived regions of Appalachia. In order to develop a broader understanding of the role parental influences play in rural high school students' academic achievement and career goals, future research is needed to expand the potential significance of parents' abilities to influence achievement and goals.

\section{Statement of the Problem}

A decrease in parent involvement in the adolescent years may be due to the fact that adolescents are seeking greater autonomy at this time. Also, parents tend to feel less able to assist their children with schoolwork, as it becomes more difficult. Even though parents feel they are more influential to their children early on, adolescents need to know that their parents support them in their decision-making and educational endeavors (Booth \& Dunn, 1996).

The sample of adolescent subjects chosen for this study were considered at-risk because of rural, low-income status. Further, the period between childhood and adulthood can be a challenging one and a general lack of resources enhances the difficulty for the adolescent. Providing an adolescent with a stable, resourceful environment will most likely increase his chances of success. Research such as Bogenshneider's (1997) provided evidence that adolescents who had parents that were 
more involved in their schooling did better in school, regardless of the parents gender or education and the children's gender, ethnicity, or family structure. Adolescents need to feel secure in their decision making and know that their parents support them. How an adolescent perceives their parent's involvement is just as important as the actual involvement of the parent. There is a need to educate parents about the importance of their role in their adolescent's life, and more precisely how to be effectively involved in their lives. Research is needed to help insure a successful future for all adolescents and to increase the positive interaction between parent and child.

\section{Statement of Purpose}

The purpose of the study was to examine the relations between parents' perceptions of their influences and high school students' academic achievement and career goals. Adolescents often turn to their parents for guidance, especially about their most critical academic, career, and personal choices. Underestimating the parental role in an adolescent's life could be a mistake due to the fact that they are still the most respected and trusted people in the adolescent's life.

This research attempted to provide professionals, parents, teachers, etc. with knowledge about the roles that parents play in their adolescents' achievement and career decisions. The results helped to provide evidence to support the purpose of this study. It is also intended that further research will be conducted on parent-adolescent relations 


\section{Terminology}

The following terms are defined to limit any misunderstandings about the goals of the research.

Adolescence: The stage of development that occurs between childhood and adulthood. During this transitional period an adolescent encounters increased physical, cognitive, and social development.

Poverty: For the purpose of this study, poverty is defined in West Virginia as a family of four with a median household income of less than $\$ 20,795$.

Rural: The 1990 Census of Population for West Virginia (U.S. Department of Commerce, 1992) defined rural as areas containing a population of less than 2,500. For purposes of this study, this definition was expanded to include non-urban areas with 3,000 people or less.

Gender: refers to an individual's classification as male or female.

Ethnicity: part of an individual's self-determination by his or her belonging to a particular ethnic group.

Family Structure: The regulation and adaptation of boundaries in the family. Contexts: the interrelated conditions, in which something exists or occurs in a family setting or environment.

Intrafamilial processes: processes that occur within the family.

Ontogenetic factors: biological factors related to the development of an individual.

Resiliency: the ability to adjust to adverse situations. 


\section{Summary}

This chapter provided an overview of the study, justification of the research, a statement of the problem, and a statement of the purpose. The next section includes existing research pertaining to the effects of specific parental influences on high school students' outcomes. 


\section{Chapter II}

\section{Review of Literature}

\section{$\underline{\text { Overview }}$}

Bronfenbrenner (1977) stated that:

The ecology of human development is the scientific study of the progressive, mutual accommodation, throughout the life span, between a growing human organism and the changing immediate environments in which it lives, as this process is affected by relations obtaining within and between these immediate settings, as well as the larger social contexts, both formal and informal, in which the settings are embedded (p. 514).

There is widespread research being done on the ecological perspective of human development, specifically, the influence of external environments on the functioning of families as contexts of human development. Studies being conducted in this area include the interaction of genetics and environment in family processes, transitions and linkages between the family and other major settings influencing development, such as peers, schools, hospitals, social networks, the working world, neighbors, and communities, and public policies that affect families and children. There is also a strong emphasis placed on the effects that intrafamilial processes have on the patterning of environmental events and transitions over time.

The objective of this study was to apply a structural model in order to better understand and predict the academic achievement and career goals of adolescents. In this study parental attitudes and influences were expected to have positive effects on adolescent goals and academic achievement. It was expected to provide evidence to 
support the hypothesis that parents who are more involved in their adolescent's schooling will have children who do better in school. This applies to all parents who are actively involved regardless of the child's gender.

Research evidence exists to support the notion that parental involvement plays an important role in students' academic progress. The study examined psychological support, parental pressure, parental help, pressure for intellectual development and parental monitoring of adolescents' use of time. These are the subscales of the Inventory of Parental Influence measurement. Studies examining the influence parents have on adolescent achievement and goals were reviewed. Lastly, the hypotheses of the present study are included.

\section{$\underline{\text { Ecological Model }}$}

Ecological theory considers family influences as powerful in causing change in the individual (Bronfenbrenner, 1986) and, therefore, provides a way to interpret interactions between adolescents and their parents and to investigate how they relate to academic achievement and career goals. Ecological paradigms in the early 1960's focused almost exclusively on context (Bronfenbrenner \& Crouter, 1983). This raised valid questions regarding how intrafamilial processes are affected by extrafamilial conditions. Using the Bronfenbrenner model to illustrate research findings one can examine how the individual grows and adapts through interchanges with its environments. Many theorists believe that environment plays a little role in affecting the growth of an individual and others believe that the environment is the sole reason that an individual develops. This theory allows you to look at both aspects. The theory does a 
good job of tying together the idea that individuals are both biological and social in nature.

Proponents of Bronfenbrenner's ecological perspective of human development support studying the developmental outcomes of individuals within multiple environments. Environments can be understood as different levels of contexts in which people operate. Some of the environments are more immediate, while others are more distal. Bronfenbrenner described four specific environmental systems within which an individual develops. The microsystem is a setting with those components of an individual's environment that directly influence or are influenced by the individual. In a microsystem paradigm, the evolving person is seen as an active individual who plays some part in any developmental process that occurs in the microsystem (Bronfenbrenner, 1989). The individual plays a specified role for a specific period of time. In terms of research, the microsystem is the most explored layer of the multisystem perspective. This is probably due to the fact that it involves the active individual directly and the microsystem adapts easily in a research design.

The mesosystem consists of the interactions among the components of the microsystem and their influences on the developing individual at a particular time in his/her life. For example, family and school will intersect. The exosystem represents components of the individual's environment that have indirect influences on their development. It is an extension of the mesosystem. The structures here are further removed from the individual but still affect him (e.g., mass media). The macrosystem is different from other levels in that it does not refer to a specific context, but represents 
those values and ideas that ultimately influence individual development through their impact on components of other systems.

Bronfenbrenner has recently expanded and refined his approach. Bronfenbrenner now views his ecological theory as applying throughout the life course of the individual. He refers to this idea as the chronosystem, which incorporates time as the developmental history of the individual (events and experiences) and its effect on development (Klein \& White, 1996, p.229). Bronfenbrenner uses this multisystem perspective to examine his belief that development is the outcome not simply of the ontogenetic factors but of the interaction of the individual's genetic foundation with the immediate family and eventually with other components of the environment.

In the following sections research on parental influences and their adolescent's academic achievement and career goals will be reviewed. It is suggested that future research be done in the area of parental influences and the effect it has on determining the outcomes of academic and career goals.

\section{$\underline{\text { Parental Influences on High School Students }}$}

Bronfenbrenner's framework illustrates the interaction between the developing person and the changing context in which the individual is found (Young, Friesen, \& Pearson, 1988). The family is a microsystem that is part of a larger environmental system. Career development takes place as the individual forms diverse roles in four different environments: home, community, school and workplace (Young, Friesen, \& Borycki, 1994). The ecological model conceptualizes the family as a context that directly influences adolescent behavior. The family contributes to the development of resources that increase the likelihood of academic success and they play a mediational role in 
linking factors such as social class to adolescent academic competence (Bronfenbrenner, 1989). In a study by Young et al. (1988) parental activities and interpersonal relationships that influence adolescents' career development are summarized. A sample of 2,186 children ages 10-18 and 207 parents were interviewed about specific events and experiences parents have had in helping their adolescents in career development. The study resulted in the development of a category system organized around two elements of the microsystem, activity and interpersonal interaction, as proposed by Bronfenbrenner (1979). By constructing the category system based on Bronfenbrenner's ecological model, parental behavior influencing career development was identified (Young et al. 1988).

Articles reviewed for this study stated that parents who where more involved in the adolescent's schooling were more likely to have a greater impact on school success. Another important aspect of this study was to determine whether parental school involvement varied by the characteristics of the person and the environment. Five subscales of parental influences based on a measure used in the study (Inventory of Parental Influences) are discussed in the following sections. They are Parental Involvement/Help, Psychological Support, Parental Pressure, Pressure for Intellectual Development, and Time Management/Monitoring.

Parental Involvement/Help. Parental involvement can be difficult to specifically define because it may mean different things to different people. For the purpose of this study, parental involvement can be defined as home and school-based parent involvement activities. Evidence showing the importance of parental influences on academic achievement and career development of adolescents has been found. Trusty 
(1996) found that high school seniors who had parents that were actively involved had a better outlook regarding their future and had better school attitudes. The study had a representative sample of 9,075 high school seniors from the 1992 cross sectional sample of the National Center for Education Statistics. The data used from the analysis was from the Second Follow-up Student Survey. Parental Involvement was determined by summarizing the scores from eight items on the Student Survey. Seven of the eight items assessed the degree to which parents discussed items such as school courses, job possibilities after high school, school activities, etc. Factor analyses were performed on several items measuring students' perceptions of parental involvement in their career development. The strongest relationships between parental involvement and high school seniors were found to be attitudes about school, family and social outlook, and schoolrelated behavior. It can be interpreted that a positive environment with reasonable expectations will likely challenge a student's ability and lead to a more effective academic and professional career.

Studies of parental school involvement have established that processes functioning in one setting, the family, can affect an adolescent's behavior in another setting, the school. This illustrates what Bronfenbrenner $(1977,1979,1986)$ has termed mesosystem linkages between these two important domains in an adolescent's life (Bogenschneider, 1997). The most consistent finding was that parental involvement, such as monitoring the adolescent's progress and parental help, was more likely to increase an adolescent's academic performance regardless of the parent's gender and educational level. Bogenschneider (1997) conducted a study with 10,000 high school students. Using a Bronfenbrenner (1986) theoretical framework that integrates 
characteristics of the person, process, and context, Bogenschneider (1997) enhanced previous findings by supporting the notion that parental school involvement is a proximal process with validity across the contexts of the child's and parent's gender, parent's education, family structure, and ethnicity. The findings expanded those of previous studies by stressing the often-overlooked difference between the level of a proximal process and its effectiveness as a creator of developmental outcomes. The benefits of parental school involvement across ecological niches were primarily constant, allowing one to interpret that developmental effects of parental involvement are more powerful than environmental contexts in which they occur (Bogenschneider, 1997).

Bogenschneider (1997) found that exceptions to the cross-contextual validity of parental school involvement occurred among African American mothers and lesseducated fathers of daughters. There is very little research that provide us with some insight as to how rural African American families facilitate their children's academic competence. However, research indicated that African American parents living in rural areas named educational attainment as an important developmental goal for children (Brody, Stoneman, \& Flor, 1995). Many African Americans see education as one of few opportunities to move up in the world. This makes the question of why school success among adolescents was not related to school involvement of black mothers in Bogenschneider's study even more perplexing. Bogenschneider believed that it may be a chance finding due to the limited number of Black families in the sample. It was also found by Bogenschneider that schools were sometimes less successful in seeking the involvement of Black mothers than Black fathers or parents in other ethnic groups. 
The second exception to the positive results found in Bogenschneider's study were findings from daughters of fathers with a lower degree of education. According to Bogenschneider, parental education is believed to be associated with parental involvement. This is one case in which independence seems to outweigh conformity, leading one to believe that increased involvement with less-educated fathers may prohibit the daughter's ability to expand her academic potential (Brody et al., 1995). This supported Bronfenbrenner's mesosystem framework in that proximal processes in the family domain can limit adolescent academic success.

Bogenschneider (1997) documented that mother's and father's involvement were equally beneficial for sons and daughters, and that the involvement of single mothers was a more potent influence on school grades than was the involvement of mothers in families with a biological mother and father living together. These results supported Bronfenbrenner's mesosystem framework by showing how proximal processes in the family domain may magnify or mitigate adolescent's academic success in the school domain. It was found that there were several different significant levels of school involvement in the ecological niches discussed including the gender of child and parent, parent's education, family structure, ethnicity, etc. As previously stated, although the levels of parental school involvement varied in different ecological niches, the benefits of parental involvement to their adolescent's school achievement were primarily constant across contexts. This makes one wonder if the developmental effects of parental school involvement were more substantial than those of the environmental contexts in which they occurred. In summary, previous research on parents and their adolescents' educational and career development has shown a significant dependence on parents by 
their children leading to the conclusion that positive outcomes, such as educational achievement and career decision making tend to be related to parental involvement (Trusty, 1996).

A sample of 90 rural African American youths and their parents participated in the development of the self-report instruments and observational research methods (Brody et al., 1995). Consistent with Bronfenbrenner's ecological model that guided Brody's study, it was predicted that family processes and parent involvement would be directly linked to adolescent academic competence. Also, parental education and family financial resources would indirectly affect academic competence. The results showed that there was a positive direct effect of maternal education on maternal involvement in school. Higher maternal education was linked with lower levels of paternal involvement. Also, higher paternal education was linked with more maternal and paternal involvement in school. However, only maternal involvement was linked with academic competence.

Expectations for one's success are often times acknowledged as important factors related to outcomes such as career choice and academic achievement (Frome \& Eccles, 1998). Many times what separates successful students from those who encounter frustration in school are the behaviors and attitudes of the student. Positive perceptions of the future can result in an increase in adolescent achievement. Trusty (1996) found that an adolescent's future perceptions and aspirations were positively related to parental involvement. An environment can allow for a variety of opportunities for development. Individuals will encounter different experiences from a specific environment based on their personal perceptions. Every environment will affect an adolescent differently in terms of what they gain from it, whether it is positive or negative. One adolescent may 
view an environment with socially active parents as positive in terms of social capital, while another adolescent may view socially active parents as negative due to the lack of time spent with their parents.

Consistent with the current appeal in an ecological model and the effects of context on behavior (Bronfenbrenner, 1986), there has been recent focus on the parenting literature as to why parents parent the way they do (Belsky, 1984). Parental effectiveness is likely to be weakened by factors such as family circumstances, available resources, and peer relationships with other adults. Parenting is now perceived as a result of the interaction between characteristics of the parent, the child, and the family's circumstances (Grolnick, Weiss, McKenzie, \& Wrightmen, 1996).

In a study done by Grolnick et al. (1996), predictors of parenting during adolescence were examined and rated on three dimensions of parent involvement, autonomy support, and structure. Fifty-three mothers and 38 fathers of 13 to 18 year olds were interviewed and asked to complete a questionnaire. Results revealed that mothers who had encountered a higher number of recent stressful events had less structure and more control. For fathers, there was evidence of a relationship between parenting and adolescent views. Also, strong relations between adolescent difficulty and parenting were found in both mothers and fathers. In Grolnick's study, involvement was described as the degree to which parents are interested in their child's activities, spending time with children, and showing love and affection. In examining involvement in this sense, it was found to be positively correlated with children's achievement and negatively correlated with problem behavior. Structure was defined as the extent to which parents provide fair 
and consistent guidelines, expectations, and rules for their child (Grolnick et al., 1996). Structure was found to be related to monitoring.

Analysis from the study indicated that when parenting occurs within a supportive context, parents might adapt their behavior to characteristics of the adolescent. But, in a less supportive context, parenting may be controlled more by environmental factors and by parent's own wants or needs therefore causing parents to be less adaptive to the adolescent's characteristics.

Parental involvement should not be viewed as one specific type of involvement. Variables that may be included under the basic term parental involvement are parents' expectations of school performance, verbal encouragement, direct reinforcements, academic guidance and support, and monitoring of daily activities and school performance (Fehrmann, Keith, \& Reimers, 1987). The Fehrmann et al. study consisted of a sample of 28,051 high school seniors selected from the National Center for Education Statistics' High School and Beyond Longitudinal Study.

It was expected that parental involvement would have a direct effect on measures of academic progress. It was also determined that parental influence may, to an extent, have some indirect effects of parental involvement on grades through homework and TV viewing time. Time spent on homework and in viewing TV might improve academic learning indirectly. This is due to the parents monitoring the amount of time students spend on these activities and enhanced through parental interaction with their children at home. Research has suggested that these activities in turn influence academic achievement. Fehrmann et al. (1987) study suggested that parental involvement did have an important direct effect on grades, however indirect effect on grades through 
homework and TV was insignificant. This result implies that parents may help their high school children achieve better grades through monitoring the adolescent's daily activities and school progress, and by helping to plan future goals.

Psychological Support/Attitudes. Psychological support is defined as the positive and negative attitudes that parents apply to their children. In a recent study, a majority of students reported that parents, rather than peers, were the preferred choice of guidance when it came to educational or career decisions (Trusty, 1996). It appears that high school students depend significantly on their parents for their career development needs. Parental activities such as giving information and making suggestions are used to influence their children's decision making process. This differs from providing a child with financial help. The parent is acting as a psychological support system. Such parental activities are especially useful when they occur during open communication in which the child or adolescent is supported in discussing their interests, plans, values, and hopes for the future. Support from parents may come differently from fathers than from mothers, but, more importantly, is that parents and adolescents need to be aware of each other's views and intentions as they discuss academic and career help. Educational attainment is seen as being prepared through the encouragement and involvement of parents (Young, Friesen, \& Dillabough, 1991). Young et al. (1991) had a random sample of parents and adolescents complete a Q-sort set describing various family activities and interactions that were believed to influence career development. A primary finding of this research is that distinct parenting constructions emerge when parents and adolescents are asked to sort items pertaining to parental influence of career development. There have been 
several studies focusing on the effects of parental involvement and very little research looking at parental attitudes and how they affect an adolescent's achievements.

Children can see first hand their parents' attitudes toward education and their future. One particular article looked at the effects that family factors have on the relation between maternal employment and children's outcomes (Paulson, 1996). The study included 240 high school students. Bronfenbrenner's exosystem and microsystem were included in this study by exploring the indirect influences of maternal employment on children's achievement through mediating factors, such as parenting styles and parental involvement, within the microsystem. The macrosystem was also indirectly considered. Due to the overwhelming increase in maternal employment recently it is safe to assume that cultural views about maternal employment have changed. Parents are influenced by the views of the larger macrosystem beliefs, which can moderate the effects of maternal employment on parenting and on achievement.

Three important factors were generated from this study. Paulson (1996) found that it is not the mothers' employment status that influences adolescents' outcomes (specifically achievement), but the attitude that their choice is in the best interest of the family. Secondly, she found that regardless of the mother's role, positive parenting influenced adolescents' achievement, especially values about education and achievement. This supports the hypothesis that parental involvement at any level has a positive effect on adolescents' achievement. Lastly, adolescents' perceptions of the parents' behaviors despite how parents perceive themselves were related to positive achievement outcomes. It is also important to note that adolescents do not always perceive their parents' behaviors the same way parents do. Open communication between adolescents' and 
parents about school and perceptions of achievement is important in the sense that it allows adolescents to understand the value placed on education by their parents.

Parental Influence/Pressure. Parental pressure is defined as the expectations applied to an adolescent by his/her parental figure. It was earlier noted that parents communicate their expectations and attitudes about education and career goals. The strongest aspect of parental behavior has been found to be parental expectations and the perception of the adolescent (Patrikakou, 1997). The objective of Patrikakou's study was to explore the relationship among parental attitudes, their effects on the adolescent, and on the academic achievement of the adolescent. Many ecological theorists who look at the importance of different areas of development, such as academic achievement, tend to focus on the family as a context of human development (Patrikakou, 1997). The study used Eccles' model, which is consistent with the broader ecological theory. The sociological and psychological influences in Eccles' model can be interpreted as parts of the ecological structure of influences within the microsystem (Patrikakou, 1997). Subjects were 5,643 adolescents from a previous longitudinal study done by the National Educational Longitudinal Study. Four ethnic groups were examined in the study and several similarities were discovered among them. The strongest effects on present achievement for all four ethnic groups was prior achievement. In examining the microsystem in this study it was found that parental influences, such as participation, communication and perceptions, indirectly affected academic achievement. Combining information from both Eccles' and Bronfenbrenner's theoretical frameworks, this study placed a filtering circle around the individual and it is this circle that channeled the important influences that eventually reached the individual (Patrikakou, 1997). 
Parents must be careful as to how they convey their expectations to their children. High levels of pressure and stress may lead adolescents to make bad decisions (Patrikakou, 1997). Parenting programs focusing on developmental issues may help impact the way parents communicate their expectations to their adolescents.

In a study by Parsons, Adler, and Kaczala, (1982) the potential influence of parents as role models and expectancy socializers was examined. The process of observational learning has been recommended as a beneficial way for adolescents to integrate social norms into their lives (Parsons et al., 1982). Children will often times imitate actions and behaviors exhibited by their parents, and sometimes they will even adopt them as part of their behavior patterns. Behaviors such as hard work, resiliency, and dependability can have positive effects on children and their goals. Parents believe that they can provide their children with a strong basis for career development by influencing them to become responsible and dependable human beings (Young \& Friesen, 1992). Parsons's et al. (1982) study administered questionnaires that measured attitudes and beliefs regarding mathematics achievement to students in grades 5-11 and their parents. Parents' expectations and perceptions of their children were related to the child's awareness, task abilities, and the child's perception of parental beliefs. It was also found by Parsons et al. (1982) that children's attitudes were influenced more by their parents' attitudes about their potential than by any of their previous performances.

Parental influence needs to start at an early age and continue throughout a child's adolescence and sometimes even into adulthood. A parent's influence should not be restricted to a particular stage of a child's life but rather be a continuous collaboration between parent and child. Most parents do report that they do not wish to influence the 
specific occupational choice of their children, but do believe it is important to lay the groundwork (Young, 1994). Young (1994) discussed several factors that contribute to the domain of parental influence. These five constructs were open communication between parents and young people, the development of responsibility, the active involvement of parents in their child's lives, the encouragement of autonomy, and specific direction and parental guidance of their children. These five constructs help parents understand different approaches to parenting in different developmental stages.

Pressure for Intellectual Development/Achievement. Pressure for Intellectual Development can be described as those parental expectations that are causes and consequences of children's academic achievement. In a study conducted by Seginer (1983), it was found that the relation between parents' educational expectations and children's academic achievement has been researched from the view of parental expectations as causes and consequences of children's academic achievement. Parents have the opportunity to intervene and have an impact on their adolescent's achievement. Communicating expectations clearly is essential to an adolescent's perception of them. Parental involvement is a good way of communicating expectations. Parenting styles can have a positive or negative association with adolescent achievement.

Using a large and diverse sample of 7,836 high school students, Dornbusch, Ritter, Leiderman, Roberts and Fraleigh (1987), discussed three modes of family interaction: the authoritarian style, the permissive style, and the authoritative style. The adolescents involved in the study completed a large-scale questionnaire. The authoritarian parent attempts to control the adolescent's behaviors and attitudes according to the parent's set of standards. The permissive parenting style occurs when parents are 
accepting of the child's impulses and use very little punishment. The authoritative style encourages the child's independence and allows for open communication between parents and children. The study found that authoritative parenting was positively associated with grades. Authoritarian and permissive parenting styles were negatively associated with grades. Having a healthy and supportive environment is essential to an adolescent's success. Parents have the responsibility of taking part in the educational aspects of their child's development.

Monitoring/Time Management. Parental monitoring is the process of providing parental availability, encouragement, and guidance. Research has shown that high levels of parental involvement in school is positively associated with better student outcomes regardless of family structure (Booth \& Dunn, 1996). Strong attention needs to be centered around traditional as well as nontraditional families. Family composition does not seem to play as big a role in the outcome of an adolescent's goals as does low parental education, parental deviance from social norms, and low income (Booth \& Dunn, 1996). The parent needs to provide encouragement and support to the adolescent. The process of parenting entails availability to the child, guidance, and positive support of the adolescent's interests (Young \& Friesen, 1992). It should not consist of discouragement, total control, or a general lack of confidence. Incompetent parenting can lead to behavior problems. Adolescents who encounter competent parenting perform better across a variety of fields, including prosocial behavior, psychological development, and academic competence (Bogenschneider, Small, \& Tsay, 1997). Competent parenting, such as monitoring an adolescent's activities, may lead to less family stress, open socialization, and fewer work hours which ultimately could lead to a more 
successful adolescent. Parents who perceive adolescence as difficult may have some predetermined notions as to how their adolescent will behave. These perceptions may lead to greater control, which is likely to be responded to negatively and leading to less satisfying parent-child interactions and eventual parental withdraw from such interactions (Grolnick et al., 1996). Bogenshneider et al. (1997) examined parenting competence by administering a questionnaire to 1,227 adolescents and a mail survey to 1,176 parents. Parents who had positive perceptions of themselves had adolescents who reported higher levels of parental monitoring and responsiveness. Also, these adolescents reported lower levels of psychological control. Parenting competence can be affected by uncooperative adolescents who provide little positive feedback, thereby influencing their own development. However, if parents are able to influence their child's eagerness to be socialized through their parenting, an adolescent's success as agents of socialization may be increased and thereby making them more effective individuals (Darling \& Steinberg, 1993).

Young and Friesen (1992) examined parents' intentions in association with their adolescent's career development. Two hundred and seven parents from a wide range of socioeconomic levels were interviewed. In the interview, the parents were asked to describe specific behaviors and actions rather than widely stated attitudes about career development. A parent's intentions were found to be one aspect of a broader understanding of what caused the action. This study examined the parent's side of the series of parent-child interactions that occur and that are specifically appropriate to the study of parental influence in the career development of their adolescents. 
From an ecological perspective, both parents and adolescents make the environment in which they live. In attempting to educate adolescents about family life, it seems productive to emphasize to them that a child's outcomes are positively associated with providing their child with adequate time, attention, supervision, and security (Booth \& Dunn, 1996).

\section{Summary}

In looking at academic achievement and career goals, on-going attention by parents and students is necessary. Focusing on the variables that research indicates will increase academic achievement and career goals will improve our knowledge of how to effectively influence adolescents. This literature review discussed Bronfenbrenner's Ecological Model and how it examines the effectiveness of parental influences. It also discussed the five subscales of parental influences: Parental Involvement/Help, Psychological Support, Parental Pressure, Pressure for Intellectual Development/Achievement, and Time Management/Monitoring. The specific studies examined in this literature review looked at different aspects of parental influence. Several studies found parental influences to have positive correlations with academic achievement and career goals as was expected by the researcher. However, there were aspects of different parental influences that can be detrimental to an adolescent's achievement and goals. Psychological support that becomes controlling can have negative effects on achievement. Also, certain parenting styles, such as the authoritarian style and the permissive style were found to have negative effects on achievement. 


\section{Hypothesis/Predictions}

a) Parental Pressure will have a significant positive relation with adolescent achievement and career goals.

b) Psychological Support will have a significant positive relation with adolescent achievement and career goals.

c) Parental Help will have a significant positive relation with adolescent achievement and career goals.

d) Pressure for Intellectual Development will have a significant positive relation with adolescent achievement and career goals.

e) Monitoring/Time Management will have a significant positive relation with adolescent achievement and career goals.

f) The relations between parental pressure, psychological support, parental help, pressure for intellectual development, monitoring/time management and adolescent achievement and career goals will not share prediction of the dependent variables with gender and race. 


\section{Chapter III}

\section{Methods}

\section{$\underline{\text { Overview }}$}

This study was based on a larger study conducted at an earlier time. The present study used second year data that was already collected from the previous study. An exploratory research design was used for the present study. An adolescent's perception of goals varies greatly. Regardless of the race and gender of an adolescent, how they anticipate accomplishing goals plays a vital part in their future. A parent's attitude can have a great impact on their child's ability to set and accomplish life goals. A study of low-income rural Appalachian adolescents was completed to examine the precise impact parental influences have on adolescent achievement and career goals. As stated earlier in the Introduction, there has been little research done on low-income rural adolescents, especially African American rural adolescents.

The measures that were used in the study were completed by the adolescent and his/her parental figure. The adolescent completed the Perceived Life Chances Interview. The Inventory of Parental Influence (IPI) was completed by the parental figure. Home visits were set up to visit with the adolescent and his/her parental figure and to engage in the collection of data. Upon completion of the data collection, the data was analyzed and results were concluded.

The following study was conducted to investigate how parental influences related to high school students' achievement and career goals living in rural counties in West Virginia. The present thesis used the collected data from Dr. Carol Markstrom's study on rural, poor West Virginia high school students. The independent variable was parental 
influences. The dependent variable was adolescent achievement and goals. To obtain the goals of the study, various steps were concluded. First, the term "rural" needed to be defined so that a suitable sample of African American and European American adolescents could be located. Second, potential subjects needed to be found and screened. Lastly, there was a selection of appropriate instruments. These instruments were used to measure parental influences and high school student achievement and goals.

\section{Sample Section}

A screening procedure was used to obtain an appropriate sample for the study. The subjects had to be from rural southern West Virginia communities and from families that lived below the West Virginia median income of $\$ 20,795$. The subjects had to be either African American or European American and had to be entering the $10^{\text {th }}$ grade as of the Fall 1994. Further explanation of the requirements is provided in the following sections.

Locating Rural Areas. According to the 1990 Census of Population for West Virginia (U.S. Bureau of the Census, 1992), a rural area has fewer than 2,500 people. Rural counties in West Virginia were chosen to be used in the study. The counties selected were McDowell, Raleigh, Fayette, Greenbrier, and Logan.

Selection of Schools. The 1990 Census of Population for West Virginia stated that there was only a small percentage (3.1) of African Americans living in West Virginia, and only $1.7 \%$ of that population was living in rural areas. In an attempt to have equal numbers of African Americans and European Americans, the schools were chosen based on the percent of African American students enrolled. There are certain high schools that had higher numbers of African American students and, therefore, were 
used in the study. The high schools involved were Logan High and Man High School in Logan County, Valley High School and Oak Hill High School in Fayette County. In Raleigh County the schools used were Woodrow Wilson High School and Liberty High School, and Greenbrier West High School were used from Greenbrier County. Mountview, Big Creek, McDowell Vocational, and Nazarene Academy were used from McDowell County.

Screening Procedure. The screening of potential subjects began once the standards were established. Race, family income level, rural community, and grade level were all used for screening purposes.

The procedures were carried out by two research assistants of Dr. Carol Markstrom. There was one European American research assistant and one African American. They went to each high school and talked to the students. Students were then given a background information sheet (Appendix A) to complete. Based on the background sheet, students who were not African American or European American were excluded from the study. The background information sheet included the student's phone number and/or address so that future contact could be made.

Using the racial data that was provided voluntarily by students, potential subjects were sent a second background sheet requesting parent data (Appendix B). This background sheet was the second tool used to screen subjects out. It provided family income information. Letters had to be sent out to parents of interested students explaining the study once eligibility was determined.

Final Sample. Statistical analysis was conducted on 124 subjects' data--100 adolescents and their mothers and 35 adolescents and their fathers. Some adolescents 
were analyzed twice because both of their parents participated in the study. Out of the 35 fathers who provided data, 21 had sons and 14 had daughters in the study. Also, 27 of the subjects were African American and 8 were European American. From the 100 mothers who provided data, 66 had daughters and 34 had sons. Also, 52 of the subjects were European American and 48 were African American.

The final sample contained 83 subjects that continued from the first year and 41 subjects were added the second year. Almost all subjects were from rural areas with the exception of some subjects obtained for the second year of the study. These subjects were from Beckley, which is a non-urban town as opposed to a rural community.

\section{$\underline{\text { Data Collection Procedure }}$}

The data used for this study comes from the second year of the data collection. After eligibility was determined, appointments had to be scheduled in the participants' homes. Home-visits were made by the research teams. Research teams were made up of a graduate student and an undergraduate student, either European American or African American, depending on the race of the subject. Each visit ended up being approximately one to two hours. During the home-visit, the adolescent and his/her parental figures filled out questionnaires and completed interview sessions. The graduate student worked with the parental figures and the undergraduate worked with the adolescents. To ensure privacy, the procedures were conducted in separate rooms.

The adolescent interviews were conducted separately from the parent interviews. Two members of a research team visited each adolescent and his/her family. The research team was of the same race as the families they visited. Adolescents were provided with assent forms explaining the purpose of the study, procedure and 
confidentiality (see Appendix C). The form had to be signed and dated by the adolescent and the research assistant. The parent was given a consent form to allow the adolescent to be in the study (see Appendix D).

Upon completion of the assent form, the questionnaires were administered by the undergraduate student. The undergraduate was available to answer any questions or concerns. The researchers checked to see that all questions had been answered and that nothing was left blank by using a Home-Visit Checklist (see Appendix E). Once the procedures were finished, a gift of $\$ 10$ was given to the adolescent for participation in the study.

The parental figure had to sign another consent form that described the participating subjects as volunteers and allowed the process of data collection to begin with the parent (see Appendix F). The graduate student was there to answer any questions the parent might have concerning the study before distributing the questionnaires.

\section{Instruments}

The measures that were used in this study were taken from a larger longitudinal study that had been conducted earlier. The adolescents completed the Perceived Life Chances Interview. The parental figure completed the Inventory of Parental Influence. There was a separate form for the father and the mother. Each measure will be discussed in detail in the following sections.

Perceived Life Chances Interview. The adolescents were given the 10-item measure and asked to complete it during a home visit with the assistance of one of the research assistants (see Appendix G). The Perceived Life Chances Interview was 
adopted from Jessor and Jessor (1997) by Dr. Carol Markstrom and set up to obtain data about an adolescent's perception about his/her future. The research assistant provided the subjects with the instructions. The subjects were asked to answer the questions as realistically and honestly as possible. The research assistant was responsible for reading the questions aloud and recording the answers. The Interview was qualitatively analyzed as part of the present thesis.

Inventory of Parental Influence. The parental figure was given the 52-item measure and asked to complete it during a home visit with one of the research assistants (see Appendix H). The Inventory of Parental Influence is a series of items designed to identify a family member's perceptions of the following family processes: Parental Pressure, Psychological Support, Parental Help, Pressure for Intellectual Development (PID), and Monitoring/Time Management (MTM) (Campbell, 1994). These are the subscales of the measurement. This is a two-part measure. In the first part the items are rated on a five-point Likert scale using responses of: (1) strongly agree, (2) disagree, (3) uncertain, (4) agree, and (5) strongly agree. The two subscales of Part One are parental pressure and psychological support. The second part contains items that are rated on a five-point frequency scale using responses of: (1) never, (2) rarely, (3) sometimes, (4) usually, and (5) always. The three subscales in Part Two are parental help, pressure for intellectual development, and monitoring/time management. To show reliability of the measure, alpha reliability coefficients were calculated for each of the different scales. The alpha levels for each subscale were as follows: Pressure (alpha $=.76$ ), Psychological Support $($ alpha $=.71)$, Parental Help $($ alpha $=.85)$, Pressure for Intellectual Development $($ alpha $=.83)$, and Monitoring/Time Management $($ alpha $=.76)($ Campbell, 1994). 


\section{Chapter IV}

\section{Results}

\section{Overview of Statistical Analysis}

Both qualitative and quantitative research designs were used in this study.

Two measurements were examined and evaluated to determine statistical significance.

They included the Perceived Life Chances Interview and the Inventory of Parental Influence (IPI). Before beginning the process of statistical analysis, some questions from the Perceived Life Chances Interview were examined to determine categories for coding purposes. It was necessary to transfer questions that were qualitative to quantitative. Statistical analysis were conducted on 124 subjects' data--100 adolescents and their mothers and 35 adolescents and their fathers. Some adolescents were analyzed twice because both of their parents participated in the study. Out of the 35 fathers who provided data, 21 had sons and 14 had daughters in the study. Also, 27 of the subjects were African American and 8 were European American. From the 100 mothers who provided data, 66 had daughters and 34 had sons. Also, 52 of the subjects were European American and 48 were African American.

Discriminant function analysis and regression analysis were used to assess each dependent variable of the Perceived Life Chances Interview. Discriminant function analyses were run for each dependent variable that was categorical. A regression analysis was run for each dependent variable that was continuous. Separate analyses were run for reports from mothers and fathers. The subscales of the Inventory of Parental Influence-parental pressure, psychological support, parental help, pressure for intellectual development, and monitoring/time management--along with gender and race served as 
independent or predictor variables to determine if they were related to adolescent achievement or career goals as measured in the Perceived Life Chances Interview.

\section{$\underline{\text { Reliability of Inventory of Parental Influence }}$}

Prior to conducting the primary analysis, reliability was established for the Inventory of Parental Influence. Cronbach's alphas of the maternal and paternal subscales were between .59 and .84 , respectively, with the exception of paternal support which had an alpha of .38 (see Table 1).

Table 1

Cronbach's Alphas of all Maternal and Paternal Subscales of the Inventory of Parental Influence.

\begin{tabular}{ll} 
Variables & Alpha Level \\
\hline Maternal Pressure & .70 \\
Maternal Support & .59 \\
Maternal Help & .77 \\
Maternal Pressure for Intellectual Dev. & .81 \\
Maternal Monitoring/Time Management & .83 \\
Paternal Pressure & .79 \\
Paternal Support & .38 \\
Paternal Help & .84 \\
Paternal Pressure for Intellectual Dev. & .76 \\
Paternal Monitoring/Time Management & .75
\end{tabular}




\section{Qualitative Analysis}

Before the statistical analysis was conducted, specific questions from the Perceived Life Chances Measure needed to be transferred into categories. Questions 1, 2, $3 \mathrm{~b}, 4 \mathrm{~b}, 7,9$, and 10 from the 10-item measure were individually separated and adolescent responses were then broken down into categories and a coding system was developed. After the 10 items were coded, the study ended up with several dependent variables. Question 1 was assessed in two ways. It was assessed as a continuous variable and as a categorical variable. As a continuous variable, question 1 divided career responses into SES classification. As a categorical variable, question 1 required the adolescents to state what job they would like to obtain after their education. Every adolescent response was put into one of six categories--Legal, Education/Public Service, Health/Science, Arts/Entertainment, Computer/Business, and Unknown. Questions 2, 3b, 4b, 7, 9, and 10 were handled the same way with their own specific categories devised based on participants' answers (see Table 2). The number of possible responses for a question varied depending on the number of categories developed. Also, an adolescent may have indicated more than one response for questions 2, 7, 9, and 10. After the categories were set, inter-rater reliability was established (see Table 2).

Twenty randomly selected Perceived Life Chances Interviews were coded separately by the principal investigator and another graduate student to determine interrater reliability. An 80 percent or higher reliability was established for questions 1, 2, 3b, 4b, 7, 9, and 10. The remaining questions from the Perceived Life Chances Interview were already categorical, so they were easily codeable. 
Table 2

Categories and Inter-Rater Reliability Established for Dependent Variables.

\begin{tabular}{|c|c|c|}
\hline & Categories & $\begin{array}{l}\text { Inter-rater } \\
\text { reliability }\end{array}$ \\
\hline $\begin{array}{l}\text { 1. What job would you like to have } \\
\text { when you're finished with your } \\
\text { education? } *\end{array}$ & $\begin{array}{l}\text { Legal } \\
\text { Education/Public Service } \\
\text { Health/Science } \\
\text { Arts/Entertainment } \\
\text { Computer/Business } \\
\text { Unknown }\end{array}$ & $80 \%$ \\
\hline $\begin{array}{l}\text { 2. What are the things you feel } \\
\text { might stand in the way of your } \\
\text { getting this job? } * *\end{array}$ & $\begin{array}{l}\text { Personal/Environmental Barriers } \\
\text { Lack of Educ/Acad Shortcomings } \\
\text { Racism/Sexism } \\
\text { Financial Difficulty } \\
\text { Family/Relationships } \\
\text { None at all }\end{array}$ & $91 \%$ \\
\hline $\begin{array}{l}\text { 3b. When would you like to get } \\
\text { married? * }\end{array}$ & $\begin{array}{l}19 \mathrm{yrs}>\text { under } \\
20 \mathrm{yrs}-29 \mathrm{yrs} \\
30 \mathrm{yrs}-40 \mathrm{yrs} \\
\text { unknown }\end{array}$ & $96 \%$ \\
\hline $\begin{array}{l}\text { 4b. When would you like to have } \\
\text { children? } *\end{array}$ & $\begin{array}{l}19 y r s>\text { under } \\
20 y r s-29 y r s \\
30 y r s-39 y r s \\
\text { unknown }\end{array}$ & $80 \%$ \\
\hline $\begin{array}{l}\text { 7. What are the most important } \\
\text { reasons that might keep you from } \\
\text { getting all of the schooling that you } \\
\text { would like? } * *\end{array}$ & $\begin{array}{l}\text { Academic } \\
\text { Health/Medical } \\
\text { Family/Personal Relationships } \\
\text { Financial/Economic } \\
\text { Nothing } \\
\text { Miscellaneous }\end{array}$ & $94 \%$ \\
\hline $\begin{array}{l}\text { 9. What sorts of things will you be } \\
\text { doing after high school to make you } \\
\text { feel like you are right on track in } \\
\text { life? } * *\end{array}$ & $\begin{array}{l}\text { Working } \\
\text { Schooling } \\
\text { Independence/Ownership } \\
\text { Personal goals } \\
\text { Religious beliefs } \\
\text { other }\end{array}$ & $100 \%$ \\
\hline $\begin{array}{l}\text { 10. After all of your schooling, } \\
\text { what will make you feel like you are } \\
\text { making a success of things? } * *\end{array}$ & $\begin{array}{l}\text { Job/Money } \\
\text { Family } \\
\text { Independence/Ownership } \\
\text { Personal goals }\end{array}$ & $100 \%$ \\
\hline
\end{tabular}

\footnotetext{
* One category per respondent.
}

** Answers allowed for more than one category. 


\section{Quantitative Analysis}

Discriminant function analysis was then performed for each categorical variable.

Discriminant function analysis is similar to multiple regression in that both statistical techniques involve two or more predictor variables and a single criterion variable.

Discriminant analysis, however, is limited to the special case in which the criterion is a categorical variable. Each discriminant function analysis that was run yielded results that included Eigenvalues, Wilk's Lambdas, Canonical Correlations, and Chi-Squares (see Tables 3 and 4). The tables also includes the results of the percent correctly classified by the function versus chance. After analyzing the maternal data, eight of the 42 functions were found to be significant. Three of the 42 functions were found to be significant after analyzing the paternal data. The following section will discuss each dependent variable that made a large contribution to the overall significant functions.

Two multiple regression analyses (for mothers and fathers) were conducted on one of the dependent variables (Question 1 from the Perceived Life Chances Interview) due to it being a continuous variable. Adolescents responded with their aspiring career choice, and these responses were transferred into socioeconomic status based on occupational choice. The Nakao and Treas (1992) Socioeconomic Index of Occupations is considered to be the best choice at present for determining status scores from job codes (Entwisle \& Astone, 1994). Significance was found in relation to the maternal data, but not with the paternal data. 
Table 3

Eigenvalues, Wilk's Lambdas, Canonical Correlations, Chi-Square Values, and Classification Results for Discriminant Functions for Maternal Data.

\begin{tabular}{|c|c|c|c|c|c|c|c|}
\hline & & Eigenvalue & $\begin{array}{c}\text { Wilk's } \\
\text { Lambda } \\
\end{array}$ & $\begin{array}{c}\text { Canonical } \\
\text { Correlation } \\
\end{array}$ & $\begin{array}{c}\text { Chi- } \\
\text { square }\end{array}$ & $\begin{array}{l}\text { Chance } \\
\text { Class \% } \\
\end{array}$ & $\begin{array}{l}\text { Correct } \\
\text { Class \% } \\
\end{array}$ \\
\hline 1 & $\begin{array}{l}\text { Job when finished } \\
\text { education }\end{array}$ & .390 & .542 & .529 & $56.63^{*}$ & 16.6 & 48.0 \\
\hline 2 & Barriers & & & & & & \\
\hline $2 \mathrm{a}$ & $\begin{array}{l}\text { Personal/Envir. } \\
\text { Barriers }\end{array}$ & .171 & .854 & .382 & $14.88^{*}$ & 50 & 80.0 \\
\hline $2 b$ & $\begin{array}{l}\text { Lack of } \\
\text { Education }\end{array}$ & .101 & .908 & .303 & 9.12 & 50 & 67.0 \\
\hline $2 c$ & Racism/Sexism & .167 & .857 & .378 & $14.56 *$ & 50 & 93.0 \\
\hline $2 d$ & $\begin{array}{l}\text { Family/Rel } \\
\text { Barriers }\end{array}$ & .103 & .907 & .305 & 9.26 & 50 & 87.0 \\
\hline $2 \mathrm{e}$ & Financial Barriers & .053 & .950 & .225 & 4.90 & 50 & 76.0 \\
\hline $2 f$ & None at all & .037 & .965 & .188 & 3.39 & 50 & 92.0 \\
\hline $3 a$ & $\begin{array}{l}\text { Think marriage } \\
\text { sometime }\end{array}$ & .165 & .801 & .376 & 20.90 & 33.3 & 70.0 \\
\hline $3 b$ & $\begin{array}{l}\text { When they want } \\
\text { marriage }\end{array}$ & .199 & .740 & .407 & 28.19 & 25 & 52.0 \\
\hline $4 a$ & $\begin{array}{l}\text { Think children } \\
\text { sometime }\end{array}$ & .077 & .885 & .268 & 11.53 & 33.3 & 75.0 \\
\hline $4 b$ & $\begin{array}{l}\text { When they want } \\
\text { children }\end{array}$ & .201 & .718 & .409 & 30.96 & 25 & 59.0 \\
\hline
\end{tabular}




\begin{tabular}{|c|c|c|c|c|c|c|c|}
\hline & & Eigenvalue & $\begin{array}{c}\text { Wilk's } \\
\text { Lambda }\end{array}$ & $\begin{array}{c}\text { Canonical } \\
\text { Correlation }\end{array}$ & $\begin{array}{c}\text { Chi- } \\
\text { Square }\end{array}$ & $\begin{array}{l}\text { Chance } \\
\text { Class \% } \\
\end{array}$ & $\begin{array}{l}\text { Correct } \\
\text { Class \% }\end{array}$ \\
\hline 5 & After H.S. & & & & & & \\
\hline $5 \mathrm{a}$ & $\begin{array}{l}\text { Business/Trade } \\
\text { after H.S. }\end{array}$ & .071 & .908 & .258 & 9.03 & 33.3 & 56.0 \\
\hline $5 b$ & College after H.S. & .191 & .785 & .401 & 22.71 & 33.3 & 77.0 \\
\hline $5 c$ & Job after H.S. & .017 & .983 & .129 & 1.59 & 33.3 & 77.0 \\
\hline $5 d$ & $\begin{array}{l}\text { Marriage after } \\
\text { H.S. }\end{array}$ & .221 & .789 & .425 & 22.26 & 33.3 & 83.0 \\
\hline $5 e$ & Service after H.S. & .149 & .829 & .360 & 17.67 & 33.3 & 85.0 \\
\hline 6 & $\begin{array}{l}\text { Expected } \\
\text { Schooling }\end{array}$ & & & & & & \\
\hline $6 a$ & Finish H.S. & .147 & .818 & .358 & 18.85 & 33.3 & 89.0 \\
\hline $6 \mathrm{~b}$ & Finish Bus/Trade & .108 & .862 & .312 & 13.97 & 33.3 & 71.0 \\
\hline $6 \mathrm{c}$ & $\begin{array}{l}\text { Finish 2yrs } \\
\text { college }\end{array}$ & .178 & .823 & .389 & 18.28 & 33.3 & 62.0 \\
\hline $6 \mathrm{~d}$ & Finish 4ys college & .217 & .774 & .422 & $24.04 *$ & 33.3 & 58.0 \\
\hline $6 \mathrm{e}$ & Finish grad/Prof & .155 & .806 & .366 & 20.30 & 33.3 & 60.0 \\
\hline 7 & Barriers & & & & & & \\
\hline $7 \mathrm{a}$ & Academic Barrier & .162 & .861 & .373 & $14.19^{*}$ & 50 & 76.0 \\
\hline $7 \mathrm{~b}$ & Health Barrier & .071 & 933 & .258 & 6.51 & 50 & 94.0 \\
\hline $7 \mathrm{c}$ & $\begin{array}{l}\text { Family/Pers } \\
\text { Barrier }\end{array}$ & .101 & .908 & .303 & 9.08 & 50 & 71.0 \\
\hline $7 \mathrm{~d}$ & $\begin{array}{l}\text { Financ/Econ } \\
\text { Barrier }\end{array}$ & .105 & .905 & .309 & 9.48 & 50 & 64.0 \\
\hline $7 \mathrm{e}$ & Nothing & .146 & .873 & .357 & 12.87 & 50 & 94.0 \\
\hline
\end{tabular}




\begin{tabular}{|c|c|c|c|c|c|c|c|}
\hline & & Eigenvalue & $\begin{array}{c}\text { Wilk's } \\
\text { Lambda }\end{array}$ & $\begin{array}{c}\text { Canonical } \\
\text { Correlation }\end{array}$ & $\begin{array}{c}\text { Chi- } \\
\text { Square }\end{array}$ & $\begin{array}{l}\text { Chance } \\
\text { Class \% }\end{array}$ & $\begin{array}{l}\text { Correct } \\
\text { Class \% }\end{array}$ \\
\hline $7 f$ & Miscellaneous & .093 & .915 & .292 & 8.39 & 50 & 97.0 \\
\hline 8 & $\begin{array}{l}\text { Parent } \\
\text { expectations }\end{array}$ & & & & & & \\
\hline $8 a$ & $\begin{array}{l}\text { Parents want } \\
\text { business }\end{array}$ & .098 & .849 & .299 & 15.39 & 33.3 & 53.0 \\
\hline $8 b$ & $\begin{array}{l}\text { Parents want } \\
\text { college }\end{array}$ & .193 & .815 & .402 & 19.18 & 33.3 & 90.0 \\
\hline $8 \mathrm{c}$ & Parents want job & .163 & .860 & .374 & $14.24 *$ & 33.3 & 76.0 \\
\hline $8 d$ & $\begin{array}{l}\text { Parents want } \\
\text { marriage }\end{array}$ & .206 & .794 & .413 & 21.71 & 33.3 & 74.0 \\
\hline $8 \mathrm{e}$ & $\begin{array}{l}\text { Parents want } \\
\text { service }\end{array}$ & .192 & .725 & .401 & $30.17^{*}$ & 33.3 & 84.0 \\
\hline 9 & $\begin{array}{l}\text { On track after } \\
\text { H.S. }\end{array}$ & & & & & & \\
\hline $9 \mathrm{a}$ & Working & .045 & .957 & .207 & 4.12 & 50 & 69.0 \\
\hline $9 b$ & Schooling & .234 & .810 & .436 & $19.89^{*}$ & 50 & 81.0 \\
\hline $9 \mathrm{c}$ & Indep/Ownership & .108 & .902 & .312 & 9.70 & 50 & 90.0 \\
\hline $9 d$ & Personal goals & .028 & .973 & .165 & 2.60 & 50 & 90.0 \\
\hline $9 \mathrm{e}$ & Religious Beliefs & .059 & .944 & .237 & 5.45 & 50 & 98.0 \\
\hline $9 f$ & Other & .103 & .907 & .305 & 9.24 & 50 & 100.0 \\
\hline 10 & Success in life & & & & & & \\
\hline $10 \mathrm{a}$ & Job/Money & .143 & .875 & .354 & 12.63 & 50 & 76.0 \\
\hline $10 \mathrm{~b}$ & Family & .083 & .923 & .277 & 7.54 & 50 & 62.0 \\
\hline $10 \mathrm{c}$ & Indep/Ownership & .094 & .914 & .293 & 8.48 & 50 & 65.0 \\
\hline $10 \mathrm{~d}$ & Personal goals & .061 & .942 & .240 & 5.61 & 50 & 87.0 \\
\hline
\end{tabular}


Table 4

Eigenvalues, Wilk's Lambdas, Canonical Correlations, Chi-Square Values, and Classification Results for Discriminant Functions for Paternal Data.

\begin{tabular}{|c|c|c|c|c|c|c|c|}
\hline & & Eigenvalue & $\begin{array}{l}\text { Wilk's } \\
\text { Lambda }\end{array}$ & $\begin{array}{c}\text { Canonical } \\
\text { Correlation }\end{array}$ & $\begin{array}{l}\text { Chi- } \\
\text { square }\end{array}$ & $\begin{array}{c}\text { Chance } \\
\text { Class } \\
\%\end{array}$ & $\begin{array}{l}\text { Correct } \\
\text { Class \% }\end{array}$ \\
\hline 1 & $\begin{array}{l}\text { Job when finished } \\
\text { education }\end{array}$ & .737 & .311 & .651 & 32.72 & 16.6 & 71.4 \\
\hline 2 & Barriers & & & & & & \\
\hline $2 \mathrm{a}$ & $\begin{array}{l}\text { Personal/Envir. } \\
\text { Barriers }\end{array}$ & .258 & .795 & .453 & 6.77 & 50 & 77.1 \\
\hline $2 b$ & $\begin{array}{l}\text { Lack of } \\
\text { Education }\end{array}$ & .296 & .772 & .478 & 7.64 & 50 & 74.3 \\
\hline $2 \mathrm{c}$ & Racism/Sexism & .299 & .770 & .480 & 7.72 & 50 & 94.3 \\
\hline $2 d$ & $\begin{array}{l}\text { Family/Rel } \\
\text { Barriers }\end{array}$ & .074 & .931 & .262 & 2.10 & 50 & 85.7 \\
\hline $2 \mathrm{e}$ & Financial Barriers & .397 & .716 & .533 & 9.86 & 50 & 68.6 \\
\hline $2 \mathrm{f}$ & None at all & .091 & .916 & .289 & 2.58 & 50 & 97.1 \\
\hline $3 a$ & $\begin{array}{l}\text { Think marriage } \\
\text { sometime }\end{array}$ & .327 & .634 & .496 & 13.20 & 33.3 & 68.6 \\
\hline $3 b$ & $\begin{array}{l}\text { When they want } \\
\text { marriage }\end{array}$ & .355 & .627 & .512 & 13.29 & 25 & 51.4 \\
\hline $4 a$ & $\begin{array}{l}\text { Think children } \\
\text { sometime }\end{array}$ & .558 & .521 & .598 & 18.90 & 33.3 & 85.7 \\
\hline $4 b$ & $\begin{array}{l}\text { When they want } \\
\text { children }\end{array}$ & 1.090 & .348 & .722 & 30.09 & 25 & 71.4 \\
\hline
\end{tabular}




\begin{tabular}{|c|c|c|c|c|c|c|c|}
\hline & & Eigenvalue & $\begin{array}{c}\text { Wilk's } \\
\text { Lambda }\end{array}$ & $\begin{array}{c}\text { Canonical } \\
\text { Correlation }\end{array}$ & $\begin{array}{c}\text { Chi- } \\
\text { Square }\end{array}$ & $\begin{array}{c}\text { Chance } \\
\text { Class } \\
\% \\
\end{array}$ & $\begin{array}{l}\text { Correct } \\
\text { Class \% }\end{array}$ \\
\hline 5 & After H.S. & & & & & & \\
\hline $5 \mathrm{a}$ & $\begin{array}{l}\text { Business/Trade } \\
\text { after H.S. }\end{array}$ & .270 & .732 & .461 & 9.06 & 33.3 & 65.7 \\
\hline $5 b$ & College after H.S. & .753 & .428 & .655 & $24.62^{*}$ & 33.3 & 85.7 \\
\hline $5 c$ & Job after H.S. & .125 & .889 & .333 & 3.470 & 33.3 & 77.1 \\
\hline $5 d$ & $\begin{array}{l}\text { Marriage after } \\
\text { H.S. }\end{array}$ & .201 & .833 & .409 & 5.40 & 33.3 & 82.9 \\
\hline $5 \mathrm{e}$ & Service after H.S. & .383 & .548 & .526 & 17.44 & 33.3 & 94.3 \\
\hline 6 & $\begin{array}{l}\text { Expected } \\
\text { Schooling }\end{array}$ & & & & & & \\
\hline $6 a$ & Finish H.S. & .894 & .368 & .687 & $28.96^{*}$ & 33.3 & 97.1 \\
\hline $6 b$ & Finish Bus/Trade & .564 & .553 & .601 & 17.19 & 33.3 & 65.7 \\
\hline $6 c$ & $\begin{array}{l}\text { Finish 2yrs } \\
\text { college }\end{array}$ & .490 & .509 & .574 & 19.56 & 33.3 & 65.7 \\
\hline $6 \mathrm{~d}$ & Finish 4ys college & .496 & .545 & .576 & 17.60 & 33.3 & 71.4 \\
\hline $6 f$ & Finish grad/Prof & .322 & .629 & .493 & 13.45 & 33.3 & 74.3 \\
\hline 7 & Barriers & & & & & & \\
\hline $7 \mathrm{a}$ & Academic Barrier & .407 & .711 & .538 & 10.08 & 50 & 88.6 \\
\hline $7 b$ & Health Barrier & .229 & .814 & .432 & 6.08 & 50 & 100 \\
\hline $7 \mathrm{c}$ & $\begin{array}{l}\text { Family/Pers } \\
\text { Barrier }\end{array}$ & .126 & .888 & .334 & 3.49 & 50 & 71.4 \\
\hline $7 d$ & $\begin{array}{l}\text { Financ/Econ } \\
\text { Barrier }\end{array}$ & .196 & .836 & .405 & 5.27 & 50 & 65.7 \\
\hline $7 \mathrm{e}$ & Miscellaneous & .224 & .817 & .428 & 5.96 & 50 & 94.3 \\
\hline
\end{tabular}




\begin{tabular}{|c|c|c|c|c|c|c|c|}
\hline & & Eigenvalue & $\begin{array}{c}\text { Wilk's } \\
\text { Lambda }\end{array}$ & $\begin{array}{c}\text { Canonical } \\
\text { Correlation }\end{array}$ & $\begin{array}{l}\text { Chi- } \\
\text { Square }\end{array}$ & $\begin{array}{c}\text { Chance } \\
\text { Class } \\
\% \\
\end{array}$ & $\begin{array}{l}\text { Correct } \\
\text { Class\% }\end{array}$ \\
\hline $7 f$ & Nothing & .261 & .793 & .455 & 6.85 & 50 & 94.3 \\
\hline 8 & $\begin{array}{l}\text { Parent } \\
\text { Expectations }\end{array}$ & & & & & & \\
\hline $8 a$ & $\begin{array}{l}\text { Parents want } \\
\text { business }\end{array}$ & .484 & .536 & .571 & 18.09 & 33.3 & 65.7 \\
\hline $8 b$ & $\begin{array}{l}\text { Parents want } \\
\text { college }\end{array}$ & .909 & .476 & .690 & 21.53 & 33.3 & 97.1 \\
\hline $8 c$ & Parents want job & .254 & .798 & .450 & 6.67 & 33.3 & 88.6 \\
\hline $8 \mathrm{~d}$ & $\begin{array}{l}\text { Parents want } \\
\text { marriage }\end{array}$ & 1.224 & .316 & .742 & $33.45^{*}$ & 33.3 & 80.0 \\
\hline $8 \mathrm{f}$ & $\begin{array}{l}\text { Parents want } \\
\text { service }\end{array}$ & .454 & .568 & .559 & 16.411 & 33.3 & 71.4 \\
\hline 9 & $\begin{array}{l}\text { On track after } \\
\text { H.S. }\end{array}$ & & & & & & \\
\hline $9 \mathrm{a}$ & Working & .328 & .753 & .497 & 8.370 & 50 & 74.3 \\
\hline $9 b$ & Schooling & .382 & .724 & .526 & 9.540 & 50 & 80.0 \\
\hline $9 \mathrm{c}$ & Indep/Ownership & .290 & .775 & .474 & 7.501 & 50 & 94.3 \\
\hline $9 \mathrm{~d}$ & Personal goals & .424 & .702 & .546 & 10.426 & 50 & 88.6 \\
\hline $9 \mathrm{e}$ & Religious Beliefs & .262 & .792 & .456 & 6.864 & 50 & 91.4 \\
\hline $9 f$ & Other & Only one & Non- & empty & group & & \\
\hline 10 & Success in life & & & & & & \\
\hline $10 \mathrm{a}$ & Job/Money & .176 & .850 & .387 & 4.784 & 50 & 68.6 \\
\hline $10 \mathrm{~b}$ & Family & .077 & .928 & .268 & 2.201 & 50 & 68.6 \\
\hline $10 \mathrm{c}$ & Indep/Ownership & .359 & .736 & .514 & 9.041 & 50 & 65.7 \\
\hline $10 \mathrm{~d}$ & Personal goals & .198 & .835 & .406 & 5.320 & 50 & 85.7 \\
\hline
\end{tabular}




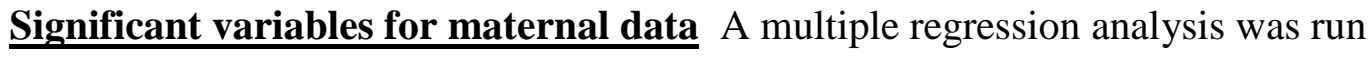
using forward selection for the socioeconomic classification continuous variable (Question 1) and the maternal independent variables along with gender and race. This was run on 96 cases. Four of the subjects did not have valid SES data. Maternal pressure, maternal support, maternal help, maternal pressure for intellectual development, maternal monitoring/time management, gender, and race were regressed on the SES variable. Gender, race, maternal support, and maternal pressure were found to significantly predict SES classification (see Table 5). Total $\mathrm{R}^{2}$ for these variables was .214. $\mathrm{Sr}^{2}$ represents the unique contribution to $\mathrm{R}^{2}$ from each variable in the equation. In other words, subtracting $\mathrm{sr}^{2}$ for a given independent variable would reduce the total $\mathrm{R}^{2}$ that amount.

\section{Table 5}

\section{Summary of Significant Multiple Regression Analyses for Continuous Dependent} Variable (SES) for Maternal Data $(\mathbf{n}=\mathbf{1 0 0})$.

\begin{tabular}{|l|c|c|c|c|c|}
\hline Variable & $\underline{\mathbf{B}}$ & $\underline{\mathbf{S E}} \underline{\mathbf{B}}$ & $\underline{\boldsymbol{\beta}}$ & $\mathbf{s r}^{2}$ & t-value \\
\hline $\begin{array}{l}\text { Step 1 } \\
\text { Gender }\end{array}$ & 11.80 & 4.03 & .30 & .11 & $3.53^{*}$ \\
\hline $\begin{array}{l}\text { Step 2 } \\
\text { Race }\end{array}$ & -8.60 & 3.74 & -.22 & .05 & $-2.39^{*}$ \\
\hline $\begin{array}{l}\text { Step 3 } \\
\text { Maternal Support }\end{array}$ & .773 & .384 & .19 & .05 & $2.50^{*}$ \\
\hline $\begin{array}{l}\text { Step 4 } \\
\text { Maternal Pressure }\end{array}$ & -.602 & .266 & -.22 & .04 & $-2.27^{*}$ \\
\hline
\end{tabular}

Note. $R^{2}=.08$ for Step $1 ; \Delta R^{2}=.05$ for Step $2 ; \Delta R^{2}=.036$ for Step $3 ; \Delta R^{2}=.045$ for Step 4 (ps $<.05)$.

$* \mathbf{p}<.05$ 
The discriminant function analysis for an adolescent's desired job when finishing their education was found to be significant, $X^{2}(35, \underline{N}=100)=56.63, \underline{p}<.012$. More specifically, gender was significant in the univariate test, $\underline{\mathrm{F}}(5,94)=4.80, \underline{\mathrm{p}}<.001$. The standardized canonical coefficient was 1.03 and the pooled within-groups coefficient was .80. Females were more likely to indicate preferences for careers in categories of Legal, Education/Public Service, and Health/Science. Males indicated they were more likely to pursue careers in Arts/Entertainment and Computer/Business fields (see Table 6)

\section{Table 6}

Means for Adolescents' Desired Job when Finished with Education (n=100).

\begin{tabular}{lccccccc}
\hline Legal & $\begin{array}{c}\text { Educ/Public } \\
\text { Service }\end{array}$ & $\begin{array}{c}\text { Health/ } \\
\text { Science }\end{array}$ & Arts/Ent & $\begin{array}{c}\text { Computer/ } \\
\text { Business }\end{array}$ & Unknown & Total \\
\hline Gender $*$ & 1.0000 & .5500 & .8000 & .3000 & .4286 & .5000 & .6600 \\
\hline
\end{tabular}

* A male was coded as $\mathbf{0}$ and females as 1

Personal and Environmental barriers was found to be significant, $X^{2}(7, \underline{N}=100)$

$=14.88, \underline{\mathrm{p}}<.038$. Again, gender was significant in the univariate test, $\underline{\mathrm{F}}(1,98)=8.42, \underline{\mathrm{p}}$

$<.005$. The standardized canonical coefficient was .82 and the pooled within-groups coefficient was .71. The mean indicated that males, more so than females, felt that Personal or Environmental barriers could keep them from obtaining the job they wanted (see Table 7).

\section{Table 7}

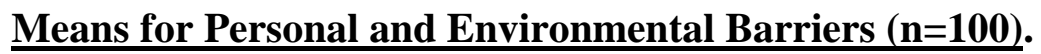

not indicated

Gender *

.7308

\section{total}

.6600

\footnotetext{
* A male was coded as $\mathbf{0}$ and females as 1
} 
Racism and Sexism barriers was found to be significant, $X^{2}(7, \underline{\mathrm{N}}=100)=14.56$, $\underline{\mathrm{p}}<.042$. Maternal pressure was marginally significant in the univariate test, $\underline{\mathrm{F}}(1,98)=$ $3.50, \underline{p}<.064$. The standardized canonical coefficient was .68 and the pooled withingroups coefficient was .46. Lower maternal pressure was associated with those who indicated this barrier (see Table 8). Race also was significant in the univariate test, $\underline{\mathrm{F}}(1$, $98)=5.63, \underline{p}<.020$. The standardized canonical coefficient was .66 and the pooled within-groups coefficient was .59. African Americans were more likely to indicate racism and sexism as a barrier preventing them from getting the job they want (see Table 8).

\section{Table 8}

\section{Means for Racism and Sexism Barriers $(\mathbf{n}=100)$.}

\begin{tabular}{lccc}
\hline & Not indicated & indicated & total \\
\hline Maternal Pressure & 43.4565 & 38.750 & 43.0800 \\
\hline Race $* *$ & .5543 & .1250 & .5200 \\
\hline
\end{tabular}

** African Americans were coded as 0 and European Americans as 1

An adolescent's plan to finish four years of college was found to be significant, $X^{2}(14, \underline{\mathrm{N}}=100)=24.04, \underline{\mathrm{p}}<.045$. Maternal support was significant in the univariate test, $\underline{\mathrm{F}}(2,97)=3.54, \underline{\mathrm{p}}<.033$. The standardized canonical coefficient was .47 and the pooled within-groups coefficient was .46 (see Table 9). Low maternal support was associated with those who indicated they were not too sure they would finish four years of college (see Table 9). Race was also significant in the univariate test, $\underline{F}(2,97)=2.92$, $\mathrm{p}<.058$. The standardized canonical coefficient was .74 and the pooled within-groups 
coefficient was .71. More African Americans, as opposed to European Americans indicated that they were very sure they would finish four years of college and more European Americans indicated they were pretty sure they would finish four years of college (see Table 9).

\section{Table 9}

Means for Adolescents Plan to Finish Four Years of College $(\mathbf{n}=100)$.

\begin{tabular}{lcccc}
\hline & Very sure & Pretty sure & Not too sure & Total \\
\hline Maternal Support & 43.8049 & 43.2500 & 40.9355 & 42.7600 \\
\hline Race $* *$ & .3902 & .6786 & .5484 & .5200 \\
\hline
\end{tabular}

\section{** African Americans were coded as 0 and European Americans as 1}

Adolescents who indicated Academic Barriers as a potential problem was found to be significant, $X^{2}(7, \underline{N}=100)=14.19, \underline{p}<.048$. Gender was found to be significant in the univariate test, $\underline{\mathrm{F}}(1,98)=3.34, \underline{\mathrm{p}}<.071$. The standardized canonical coefficient was .42 and the pooled within-groups coefficient was .46. Males were more likely to state academic barriers as an important reason in keeping them from pursuing all the schooling they would like to accomplish (see Table 10). Maternal pressure for intellectual development was significant in the univariate test, $\underline{F}(1,98)=7.22$, $\underline{p}<.008$. The standardized canonical coefficient was .68 and the pooled within-groups coefficient was .67. High maternal pressure for intellectual development was associated with those who did not indicate academic barriers as a potential problem (see Table 10). Maternal monitoring/time management was significant in the univariate test, $\underline{\mathrm{F}}(1,98)=3.88, \underline{\mathrm{p}}<$ .052. The standardized canonical coefficient was .14 and the pooled within-groups coefficient was .50. Low maternal monitoring/time management was associated with 
those who indicated academic barriers as a potential obstacle in obtaining all the schooling they would like (see Table 10).

Table 10

Means for Adolescent Academic Barriers (n=100).

\begin{tabular}{lccc}
\hline & Not indicated & indicated & Total \\
\hline Gender $*$ & .7123 & .5185 & .660 \\
\hline $\begin{array}{l}\text { Maternal Pressure } \\
\text { for Intell. Dev. }\end{array}$ & 28.9863 & 24.9630 & 27.9000 \\
\hline $\begin{array}{l}\text { Maternal } \\
\text { Monitor/Time Man }\end{array}$ & 33.8219 & 30.0741 & 32.8100 \\
\hline
\end{tabular}

* A male was coded as 0 and females as 1

Adolescents who perceived that their parents wanted them to obtain a job after high school was found to be significant, $X^{2}(7, \underline{N}=100)=14.24, \underline{p}<.047$. Race was significant in the univariate test, $\underline{F}(1,98)=5.98, \underline{p}<.016$. The standardized canonical coefficient was .70 and the pooled within-groups coefficient was .61. European Americans were more likely to indicate that their parents want them to get a job later on. African Americans indicated that, more often than not, their parents expected them to get a job immediately after high school (see Table 11).

\section{Table 11}

Means for Parents who Desired Their Adolescents to Obtain a Job after High $\underline{\operatorname{School}(n=100)}$.

\begin{tabular}{lccc}
\hline & Right away & Later on & Total \\
\hline Race $* *$ & .4545 & .7391 & .5200 \\
\hline
\end{tabular}

\section{African Americans were coded as 0 and European Americans as 1}


Adolescents who perceived that their parents preferred they go directly into the service after high school was found to be significant, $X^{2}(14, \underline{N}=100)=30.17, \underline{p}<.007$. Gender was found to be significant in the univariate test, $\underline{F}(2,97)=7.35, \underline{p}<.001$. The standardized canonical coefficient was .32 and the pooled within-groups coefficient was .17. Males were more likely to indicate that their parents wanted them to go into the service immediately after high school. Females were more likely to indicate not at all (see Table 12). Maternal help was significant in the univariate test, $\underline{F}(2,97)=3.40, \underline{p}<$ .037. The standardized canonical coefficient was .50 and the pooled within-groups coefficient was .62. High maternal help was associated with indicating they would go into the service later on and low maternal help was associated with those whose parents preferred they go into the service right away (see Table 12). Maternal pressure was significant in the univariate test, $\underline{F}(2,97)=3.27, \underline{p}<.042$. The standardized canonical coefficient was -.73 and the pooled within-groups coefficient was -.63. Low maternal pressure was associated with those indicating their parents preferred they would go into the service later on, and high maternal pressure was associated with those indicating they would go into the service right away (see Table 12).

\section{Table 12}

\section{Means for Parents who Preferred Their Adolescent go Directly Into Service} $\underline{(\mathrm{n}=100)}$.

\begin{tabular}{lcccc}
\hline & Right away & Later on & Not at all & Total \\
\hline Gender* & .3000 & .3846 & .7532 & .6600 \\
\hline Maternal Help & 22.3000 & 28.3077 & 24.5584 & 24.8200 \\
\hline Maternal Pressure & 46.4000 & 39.3077 & 43.2857 & 43.0800 \\
\hline
\end{tabular}

\section{* A male was coded as 0 and females as 1}


The last significant variable in the maternal data, adolescents who plan on continuing school after high school, was found to be significant, $X^{2}(7, \underline{N}=100)=19.89$, $\underline{\mathrm{p}}<.006$. Gender was significant in the univariate test, $\underline{\mathrm{F}}(1,98)=12.16, \underline{\mathrm{p}}<.001$. The standardized canonical coefficient was .84 and the pooled within-groups coefficient was .73. Females indicated that they were more likely to continue school after high school (see Table 13).

\section{Table 13}

\section{Means for Adolescents who Planned on Continuing School after High School} $\underline{(n=100)}$.

\begin{tabular}{lccc}
\hline & Not indicated & indicated & Total \\
\hline Gender $*$ & .3636 & .7436 & .6600 \\
\hline
\end{tabular}

\section{* A male was coded as $\mathbf{0}$ and females as 1}

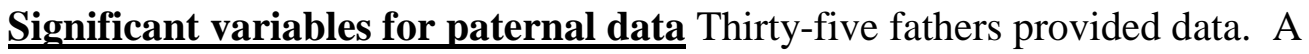
multiple regression analysis using forward selection was run for the socioeconomic classification continuous variable and the paternal independent variables along with gender and race. Paternal pressure, paternal support, paternal help, paternal pressure for intellectual development, paternal monitoring/time management, gender, and race were regressed on the SES variable. The regression was not significant.

The discriminant function analysis for the dependent variable of college after high school was found to be significant, $X^{2}(14, \underline{N}=35)=24.62, \underline{p}<.039$. Paternal Pressure was found to be marginally significant in the univariate test, $\underline{F}(2,32)=2.90, \underline{p}<.069$. The standardized canonical coefficient was .62 and the pooled within-groups coefficient 
was .65. Low paternal pressure was associated with those adolescents who indicated they would attend college right away after high school (see Table 14).

\section{Table 14}

Means for College after High School $(n=35)$.

\begin{tabular}{lcccc}
\hline & Right away & Later on & Not at all & Total \\
\hline Paternal Pressure & 44.7500 & 51.4000 & 53.0000 & 46.1714 \\
\hline
\end{tabular}

Adolescents who intended to finish high school was also found to be significant, $X^{2}(14, \underline{\mathrm{N}}=35)=28.96, \underline{\mathrm{p}}<.011$. Paternal help was significant in the univariate test, $\underline{\mathrm{F}}$ $(2,32)=3.62, \underline{p}<.038$. The standardized canonical coefficient was 1.00 and the pooled within-groups coefficient was .59. Low paternal help was associated with adolescents who were pretty sure or not too sure they would finish high school. High paternal help was associated with those who were very sure they would finish high school (see Table 15). Pressure for intellectual development was found to be marginally significant in the univariate test, $\underline{\mathrm{F}}(2,32)=3.15, \underline{\mathrm{p}}<.056$. The standardized canonical coefficient was .92 and the pooled within-groups coefficient was .60. Low pressure for intellectual development was associated with those who indicated they were pretty sure they would finish high school. High paternal pressure for intellectual development was associated with those who indicated they were not too sure they would finish high school (see Table $15)$. 
Table 15

Means for Adolescents who Intended to Finish High School (n=35).

\begin{tabular}{lcccc}
\hline & Very sure & Pretty sure & Not to sure & Total \\
\hline Paternal Help & 24.5000 & 16.0000 & 14.0000 & 23.7143 \\
\hline $\begin{array}{l}\text { Paternal Pressure } \\
\text { for Intell. Dev. }\end{array}$ & 26.4375 & 15.5000 & 32.0000 & 25.9714 \\
\hline
\end{tabular}

Lastly, a significant relationship among adolescents who perceived that their parents wanted them to get married after high school was found significant, $X^{2}(14, \underline{\mathrm{N}}=$ $35)=33.45, \underline{p}<.002$. Gender was significant in the univariate test, $\underline{\mathrm{F}}(2,32)=4.38, \underline{\mathrm{p}}<$ .021. The standardized canonical coefficient for gender was .42 and the pooled withingroups coefficient was .50 . Females indicated more often that their parents did not want them to get married at all (see Table 16). Only one male stated that his parents wanted him to get married right away. Hence, the gender finding for the right away category only applied to one subject. Race was significant in the univariate test, $\underline{F}(2,32)=3.60$, $\underline{p}$ $<.039$. The standardized canonical coefficient for race was .10 and the pooled withingroups coefficient was -.11. More European Americans indicated that their parents wanted them to get married right away (see Table 16). However, this finding is deceiving by looking at Table 16 because, in actuality, only one European American indicated that their parent wanted them to marry right away. Nine African Americans indicated that their parents did not want them to get married at all. Paternal Help was significant in the univariate test, $\underline{F}(2,32)=3.62, \underline{p}<.038$. The standardized canonical coefficient was -1.27 and the pooled within-groups coefficient was -73 . High paternal help was associated with those who indicated they would marry later on or not at all and 
low paternal help was associated with adolescents who had parents who wanted them to get married after high school (see Table 16).

Table 16

Means for Adolescents Whose Parents Wanted Them to Get Married After High School (n=35).

\begin{tabular}{lcccc}
\hline & Right away & Later on & Not at all & Total \\
\hline Gender * & .0000 & .2800 & .7778 & .4000 \\
\hline Race $* *$ & 1.0000 & .2800 & .0000 & .2286 \\
\hline Paternal Help & 14.0000 & 25.2000 & 20.6667 & 23.7143 \\
\hline
\end{tabular}

* A male was coded as 0 and females as 1

** African Americans were coded as 0 and European Americans as 1 


\section{Chapter V}

\section{Discussion}

\section{Overview of the Study}

The present study examined parental influences on educational and career aspirations of high school students. Subscales from the Inventory of Parental Influence, that is, parental pressure, parental support, parental help, pressure for intellectual development, and monitoring/time management along with gender and race were predictor or independent variables. The study involved adolescents from five counties in southern West Virginia that were determined to be rural and were at or below the West Virginia state median income level $(\$ 20,795)$. The data examined in this study was from the second year of a larger longitudinal study conducted by Dr. Carol Markstrom. The following sections discuss the results of the analyses.

\section{$\underline{\text { Parental Pressure }}$}

Prediction (a) stated that parental pressure will have a significant positive relation with adolescent achievement and career goals. Pressure can be defined as the expectations that parents put on their adolescents. For this specific study, academic and career pressure were looked at specifically. Parents responded to specific statements that dealt with parental pressure in The Inventory of Parental Influences measure, such as, a parent expecting their teenager to go to a university. Low maternal pressure was associated with those indicating they would go into the service later on, and high maternal pressure was associated with those who felt they would enter the service right away. This can be interpreted differently depending on whether one perceives entering the service as positive or negative. For this particular sample one can assume that it is 
positive since they are from a rural and economically deprived community. Entering the service would probably not be viewed as positive among middle class families because parents tend to encourage their children to attend college. Middle class families may encourage their adolescents to attend college along with the service (ROTC), as opposed to directly enlisting, hoping that they would eventually become officers Therefore, for this sample it could be interpreted that this finding does support the hypothesis.

Low maternal pressure also was associated with higher SES job classification and high maternal pressure was associated with lower SES job classification. The interpretation of parental pressure can be viewed as positive or negative depending on the amount of pressure being applied. For the purpose of this study, high parental pressure was viewed as positive. The results do not support the hypothesis because high pressure resulted in a desire for lower SES jobs. Patrikakou (1997) supported this by stating that high levels of pressure and stress may lead adolescents to make bad decisions.

Low maternal pressure was associated with those who did indicate racism and sexism as a potential problem in keeping them from getting the job they wanted. Conversely, high maternal pressure was associated with those adolescents who did not indicate racism and sexism as a barrier. Perhaps mothers who instill pressure in their children are less likely to use barriers as reasons for not obtaining their desirable job. These results support the hypothesis.

Low paternal pressure was associated with those adolescents who indicated they would attend college right away after high school and high paternal pressure was associated with those who indicated they would attend college later on. These results do not support the hypothesis. Perhaps adolescents who are more successful in school do 
not receive as much pressure because they are doing well academically and are more likely to attend college.

\section{Psychological Support}

Prediction (b) stated that psychological support will have a significant positive relation with adolescent achievement and career goals. Low maternal support was associated with those who indicated they were not too sure they would finish four years of college. High maternal support was associated with adolescents who indicated they were very sure they would finish four years of college. These results support the hypothesis. Also, high maternal support was associated with high SES classification. These results also do support the hypothesis. The support that adolescents receive from their mothers may increase their ambitions and reduce any unnecessary anxieties about obtaining a good job. Trusty (1996) supported this in his findings that students reported that parents were the preferred choice of guidance when it came to educational and career decisions.

\section{Parental Help}

Prediction (c) stated that parental help will have a significant positive relation with adolescent achievement and career goals. High maternal help was associated with those indicating they would go into the service later on. Low maternal help was associated with adolescents who indicated they would enter the service right away. Mothers who provide parental help inform the adolescent of more options, as opposed to low parental help causing the adolescent to see the service as their best option available. These results do support the hypothesis. 
High paternal help was associated with adolescents who were very sure they would finish high school, and low paternal help was associated with adolescents who were pretty sure or not to sure they would finish high school. An adolescents' desire to finish high school may be heavily influenced by the confidence given to them by their father's help. High paternal help was associated with those who indicated they would marry later on or not at all and low paternal help was associated with adolescents who perceived that their parents wanted them to get married right away after high school. Perhaps adolescents who have supporting fathers are more likely to focus on achieving individual goals first and then focus on social goals. Having supporting fathers may give them the confidence to be on their own.

\section{Pressure for Intellectual Development}

Prediction (d) stated that pressure for intellectual development will have a significant positive relation with adolescent achievement and career goals. Low maternal pressure for intellectual development was associated with those who did not indicate academic barriers as a potential problem. High maternal pressure for intellectual development was associated with adolescents who did indicate academic barriers as a problem. High expectations that are communicated effectively to adolescents can have a positive impact on adolescent achievement (Seginer, 1983). One of the positive impacts may be that adolescents are less likely to worry about underachievement. These results do support the hypothesis.

Low parental pressure for intellectual development was associated with those who indicated they were pretty sure they would finish high school and high parental pressure for intellectual development was associated with adolescents who were not too sure if 
they would finish high school. These results do not support the prediction. This may be due to excessive pressure by fathers to complete high school. Parents must be careful as to how they convey their expectations to their adolescents. As Patrikakou (1997) found, high levels of pressure and stress may lead adolescents to make bad decisions.

\section{Monitoring/Time Management}

Prediction (e) stated that monitoring/time management will have a significant positive relation with adolescent achievement and career goals. Low maternal monitoring/time management was associated with adolescents who indicated academic barriers as a potential problem in obtaining all the schooling they would like. High maternal monitoring/time management was associated with those who did not indicate academic barriers as a problem. Young and Friesen (1992) stated that the process of parenting entails availability to the child, guidance, and positive support of the adolescent's interest. Mothers who monitor their children consistently will help their adolescent to use time management effectively. Therefore, adolescents may be less likely to perceive academic barriers as a potential problem. The results do support the prediction.

\section{$\underline{\text { Results of Parental Subscales }}$}

There was some significance found in all of the maternal subscales. A few of the paternal subscales were found significant. The lack of significance among the paternal subscales was probably due to the low number of fathers who provided data. Some of the subscales were more salient than others. Parental pressure was found to be a salient subscale as it was associated with four of the dependent variables, specifically, racism and sexism barriers, SES job classification, parents who preferred their adolescent go 
directly into the service, and attending college after high school. Parental help was associated with three of the dependent variables. These were parents who preferred their adolescent go directly into the service, adolescents who intended to finish high school, and adolescents whose parents wanted them to get married after high school. Pressure for intellectual development was found to be associated with two of the dependent variables. These were adolescent academic barriers and adolescents who intended to finish high school. Monitoring/time management was only associated with one dependent variable. Monitoring time management was associated with adolescent academic barriers. Psychological support was associated with two dependent variables, specifically adolescents who planned on finishing four years of college and SES job classification. From the results, it was determined that adolescents and parents from this specific rural-economically deprived region felt that finishing high school, going into the service (for males), and continuing schooling after high school (for females) were most important to them.

\section{Gender and Race}

Prediction (f) stated that the relation between parental pressure, psychological support, parental help, pressure for intellectual development, monitoring/time management and adolescent achievement and career goals will not share prediction of the dependent variables with gender and race. The prediction or hypothesis is interested in the combination of both the parental variables and gender and race as predictors, however, many times gender was the only predictor, and in one case race was the only predictor. This made it difficult to look at shared variance with the parental variables. 
In terms of cases where gender or race were sole predictors, gender was found to predict maternal results for adolescents desired job when finished with education (more females indicated they were likely to obtain their desired job when finished with education), personal and environmental barriers (males were more likely to indicate that personal and environmental barriers could keep them from obtaining the job they wanted), and adolescents who planned on continuing school after high school (females indicated that they are more likely to continue school after high school). Race was found to predict maternal results for parents who desired their adolescents to obtain a job after high school (African Americans were more likely to indicate that there parents wanted them to obtain a job later on).

There were cases where the parental variables shared in the prediction with gender and race. Gender, along with maternal pressure for intellectual development and maternal monitoring/time management were found to predict academic barriers (males were more likely to indicate academic barriers as an important reason in keeping them from pursuing all the schooling they would like). Males may feel as if their parents want them to support themselves immediately, making them more likely to not pursue further schooling.

Gender, maternal help, and maternal pressure were found to predict parents who preferred their adolescent go directly into the service (males were more likely to indicate that their parents wanted them to go into the service right away and females were more likely to indicate not at all). It was stated earlier that going into the service right away may be perceived as positive for males. This may be their best opportunity, not only in their minds but in their parents minds as well. 
Gender, race, and paternal help were found to predict parents who wanted their adolescents to get married after high school. Specifically, females indicated more often that their parents did not want them to get married at all. Perhaps females are not encouraged to get married due to their environmental surroundings. It may be that females are more motivated to continue their schooling.

Race, along with maternal pressure, were found to predict for racism and sexism barriers (African Americans were more likely to indicate racism and sexism as a barrier preventing them from obtaining the job they want). Racism is still going on in society today. African Americans from a low-income status are even more likely to be discriminated against because of their race and their socio-economic status. Adolescents may perceive parental pressure as a warning sign that racism is a major factor.

Race and maternal support shared in the prediction of adolescents who planned to finish four years of college (more African Americans indicated that they were very sure they would finish four years of college and European Americans indicated they were pretty sure they would finish four years of college). More than likely, African Americans feel that college is their best opportunity to increase their career options and their location preferences.

Race and paternal help shared in the prediction of paternal data for adolescents who perceived that their parents wanted them to get married after high school (European Americans were more likely to indicate that their parents wanted them to get married right away). 


\section{$\underline{\text { Limitations }}$}

Various findings of the study supported the predictions that were made, but as expected, limitations were apparent in the present study. First, sample size may have been a limitation of the study. More specifically, the lack of paternal data may have reduced the potential for significance.

Another limitation may have been poor internal consistency of one of the measures. The reliability of the Paternal Support subscale of the Inventory of Parental Influence was weakened due to a low alpha level of .38.

Lastly, the predictions made in this study were derived more so by expectations for middle-class adolescents. Previous research focuses primarily on middle class families. Value systems for middle class families are different than those of lowerincome families. It may be that parents from a poor rural area may apply different parenting techniques than the ones used in this study and have different educational and career goals. Also, fathers from rural-economically-deprived regions may use different techniques of parenting than mothers do.

\section{$\underline{\text { Contributions }}$}

Little research has been conducted on at-risk adolescents, especially African Americans, living in rural, economically-deprived regions of Appalachia. The present study focused on this population of adolescents, as well as a sample of European Americans adolescents.

The findings from the study contribute more evidence that adolescents are influenced both positively and negatively by parental influences, such as parental help, parental pressure, pressure for intellectual development, psychological support, and 
monitoring/time management. This holds true for adolescents regardless of race, gender, and SES. The study raises the possibility that parents from this population (poor and rural), may use different parental influences to impact their adolescents, depending on their beliefs and upbringing. Academics may not be important to them, and they may expect their child to take over a career that is expected of them. Also, it brings about the notion of whether adolescents perceive parental involvement as positive or negative. Adolescents are striving for independence at this time, and may feel that it is being threatened by a parent who overly directs their child's life. Peers also are influential in an adolescent's life, and possibly more important in some areas of life. This is an area that future research would be very beneficial.

The fact that more African American fathers provided data in the study than European American fathers is a key aspect of the study. Twenty-seven African American fathers provided data compared to 7 European American fathers. There seemed to be a strong involvement of African American fathers with their sons. Future research in this area would be very beneficial, considering the stereotype (lack of involvement) that African American fathers have pertaining to family involvement.

\section{$\underline{\text { Future Research }}$}

In order to develop a broader understanding of the role parental influences play in an adolescent's life, future research is needed to expand the potential significance of parents' abilities to influence achievement and goals. On-going research will help provide a successful future for adolescents and to increase the positive interaction between parent and adolescent. There are several issues to examine and investigators need to determine their effectiveness. Providing continued research efforts that will 
merge methodological and theoretical developments to answer questions about the process through which families influence the opportunities and expectations of their children will help in increasing our educational goals as a nation. Establishing programs and practices to encourage positive family interactions can help promote high adolescent achievement. These programs need to be appropriate for the wide diversity in families today. Providing a system that focuses on the different ways in which parents contribute to their child's development will be more effective than criticizing parents for their lack of involvement.

If this study were to be conducted again a few suggestions would be beneficial to the researcher. A sample containing more paternal figures would allow for a more beneficial analysis of paternal influences on adolescents. Examining different parental influences may be beneficial depending on what is perceived as important to subjects being studied. A possible solution may be to do prior research on potential subjects and the expectations and desires of the general community. Individual expectations will vary, however, a broad understanding of the expectations and desires of the community would be helpful.

\section{Summary}

The purpose of the present study was to examine the effects of parental influences on educational and career goals of high school students. An effort was made to determine the effectiveness that parental influences had on adolescent achievement and career goals. Gender and race served as predictor variables. All of the maternal variables were found to have some significant relation to certain adolescent achievements and career goals. The same could not be said for the paternal variables. It was evident from 
the present research and prior research that parental influences do have an impact on adolescent achievement and career goals regardless of their ecological niche. 


\section{References}

Belsky, J. (1984). The determinants of parenting: A process model. Child Development, 55, 83-96.

Bogenschneider, K. (1997). Parental involvement in adolescent schooling: A proximal process with transcontextual validity. Journal of Marriage and the Family, 59, 718-733.

Bogenschneider, K., Small, S. A., \& Tsay, J. C. (1997). Child, parent, and contextual influences on perceived parenting competence among parents of adolescents. Journal of Marriage and the Family, 54, 345-362.

Brody, G. H., Stoneman, Z., \& Flor, D. (1995). Linking family processes and academic competence among rural African American youths. Journal of Marriage and the Family, 57, 567-579.

Bronfenbrenner, U. (1977). Toward an experimental ecology of human development. American Psychologist. 513-531.

Bronfenbrenner, U. (1979). The ecology of human development: Experiments by nature and design. Cambridge, MA: Harvard University Press.

Bronfenbrenner, U. (1986). Ecology of the family as a context for human development: Research perspectives. Developmental Psychology, 22, 723-742.

Bronfenbrenner, U. (1989). Ecological systems theory. Annals of Child Development, 6, 187-249. 
Bronfenbrenner, U., \& Crouter, A. C. (1983). The evolution of environmental models in developmental research. In P.H. Mussen (Series Ed.) \& W. Kessen (Vol. Ed.). Handbook of child psychology: Vol.1. History, theory, and methods (4th ed., pp. 357414). New York: Wiley.

Campbell, J. B. (1994). Developing cross-cultural/cross-national instruments: Using cross-national methods and procedures. International Journal of Educational Research, 21, 675-684.

Damon, W. (1983). Social and personality development. New York: W.W. Norton \& Company, Inc.

Darling, N., \& Steinberg, L. (1993). Parenting style as context: An integrative model. Psychological Bulletin, 113, 487-496.

DuBois, D. L., Eitel, S. K., \& Felner, R. D. (1994). Effects of family environment and parent-child relationship on school adjustment during the transition to early adolescence. Journal of Marriage and the Family, 56, 405-414.

Dornbusch, S. M., Ritter, P. L. Leiderman, D. F., Roberts, D. F., \& Fraleigh, M. J. (1987). The relation of parenting style to adolescent school performance. $\underline{\text { Child }}$ Development, 58, 1244-1257.

Entwisle, D. R., \& Astone, N. M. (1994). Some Practical Guidelines for Measuring Youth's Race/Ethnicity and Socioeconomic Status. Child Development, 65, $1521-1540$.

Fehrmann, P. G., Keith, T. Z., \& Reimers, T. M. (1987). Home influence on school learning: Direct and indirect effects of parental involvement on high school grades. Journal of Educational Research, 80, 330-337. 
Frome, P. M., \& Eccles, J. S. (1998). Parents influence on children's achievement-related perceptions. Journal of Personality of Social Psychology, 74, 435452.

Grolnick, W. S., Weiss, L., McKenzie, L., \& Wrightman, J. (1996). Contextual, cognitive, and adolescent factors associated with parenting in adolescence. Journal of Youth and Adolescence, 25, 33-54.

Grolnick, W., \& Ryan, R. (1989). Parent styles associated with children's selfregulation and competence in school. Journal of Educational Psychology, 81, 143-154.

Jessor, R. \& Jessor, S. L. (1977). Problem behavior and psychosocial development. New York: Academic.

Klein, D. M., \& White, J. M. (1996). Family theories. Thousand Oaks, CA: Sage Publications, Inc.

Menaghan, E. G. (1996). Family composition, family Interaction, and children's academic and behavior problems: Interpreting the data. In A. Booth, \& J. F. Dunn (Eds.), Family-school links: How do they affect educational outcomes? (pp. 185-196). Mahwah, NJ: Lawrence Erlbaum Associates, Inc.

Nakao, K., \& Treas, J. (1992). The 1989 Socioeconomic Index of Occupations: Construction from the 1989 Occupational Prestige Scores (General Social Survey Methodological Report No. 74). Chicago: University of Chicago, National Opinion Research Center.

Parsons, J., Adler, T., \& Kaczala, C. (1982). Socialization of achievement attitudes and beliefs: Parental influences. Child Development, 53, 310-321. 
Patrikakou, E. N. (1997). A model of parental attitudes and the academic achievement of adolescents. Journal of Research and Development in Education, 31, 726.

Paulson, S. E. (1996). Maternal employment and adolescent achievement revisited: An ecological perspective. Family Relations, 45, 201-208.

Scott-Jones, D. (1995). Parent-child interactions and school achievement. In B. A. Ryan, G. R. Adams, T. P. Gullotta, R. P. Weissberg, \& R. L. Hampton (Eds.), The Family-school connection: Theory, Research, and Practice (Vol 2). (pp. 75-107). Thousand Oaks, CA: Sage Publications, Inc.

Seginer, R. (1983). Parents' educational expectations and children's academic achievement: A literature review. Merrill Palmer Quarterly, 29, 1-23.

Trusty, J. (1996). Relationship of parental involvement in teens' career development to teens' attitudes, perceptions, and behavior. Journal of Research and Development in Education, 30, 63-69.

U.S. Bureau of the Census (1992). Statistical abstract of the U.S. (112th ed.). Washington, DC.

Young, R. A. (1994). Helping adolescents with career development: The active role of parents. The Career Development Quarterly, 42, 195-203.

Young, R. A. \& Friesen, J. D. (1992). The intentions of parents in influencing career development of their children. Career Development Quarterly, 40, 198-207.

Young, R. A., Friesen, J. D., \& Borycki, B. (1994). Narrative structure and parental influence in career development. Journal of Adolescence, 17, 173-191. 
Young, R. A., Friesen, J. D., \& Dillabough, J. M. (1991). Personal construction of parental influence related to career development. Canadian Journal of Counseling, 25, 183-190.

Young, R. A., Friesen, J. D., \& Pearson, H. M. (1988). Activities and interpersonal relations as dimensions of parental behavior in the career development of adolescents. Youth and Society, 20, 29-45. 
Appendix A

Adolescent Background Information 


\section{Study on West Virginia Rural Youth}

\section{Background Information}

If you are interested in learning more about this study and are willing to have us contact you, please provide the following information and return this form to us today. Providing this information does not mean you have committed to be in the study.

1. Vame

2. Address

3. Phone

4. What is your age?

What is your birthdate?

5. Are you... Male or Fernale

6. What is your current grade in school?

7. What is the name of your school?

8. Are you... African American American Indian Asian American Latino (Hispanic) White American Other (please idencify)

9. Current living arrangements (check one)

1. living with both parents

2. living with one parent mother or father

3. living with grandparents

4. living with other relatives

5. foster home

6. other (please describe)

10. What is your father's:

a) empioyment

b) level of education

12. What is your mother's:

a) employment

b) level of education 
Appendix B

Parental Background Information 


\section{ALI INFORMATION IS CONEIDENTIAL}

\section{Background Information on Parent (s)}

1. Name:

2. Address:

3. Phone:

4. Age:

Gender: Male

Eemale

5. Marital Status:

a. Single

b. Married

c. Separated

d. Widowed

e. Divorced

f. Not married, but living with partner

g. Other (please specify):

6. Racial Background (check all that apply):

-a. African-American (Black)

b. American Indian

c. Asian American

d. Latino (Hispanic)

e. White American

f. Other (please specify):

7. Are you currently employed? _Yes Y No

If yes, what do you do?

How many hours per week do you work?

If not employed, are you seeking work?

If you are seeking work, what kind are you seeking?

8. Total Household Income (combined total earnings of all

household members before deductions):

a. $\$ 4,999$ or less

b. $\$ 5,000-9,999$

c. $\$ 10,000-14,999$

d. $\$ 15,000-19,999$

e. $\$ 20,000-24,999$

f. $\$ 25,000-29,999$

g. $\$ 30,000$ or more

9. Please specify the highest education level you have achieved:

10. Please indicate the best time for you, your partner, and your teenager to be contacted:

11. If applicable, please provide the same information for the 


\section{Appendix C}

\section{Adolescent Assent Form}


College of Agriculture and Forestry

ASSENT FORM

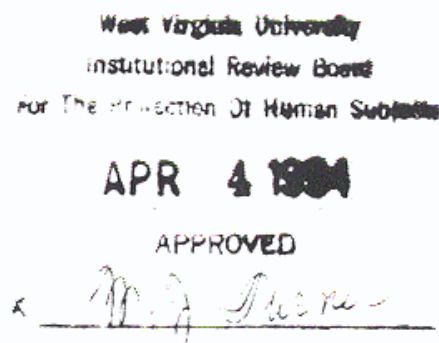

Social Processes, Coping, and Adjustment in Resilient

Economically-Deprived Rural West Virginia Youth

Introduction. I. have been asked to be in this research study, which has been explained to me by , a research assistant on this project.

Purposes of the Study. I have been told that the purpose of this study is to learn more about rural high school students in West Virginia who might be facing difficulties related to poverty and making decisions about their plans after high school.

Description of Procedures. This study will be performed in my home. I will meet privately with the research assistant. I will be given several lists of written questions to answer. The questions will be related to how I feel about myself, my family, and my life, in general. I also will be interviewed and the interview will be audiotaped. I will be asked questions about my plans for the future. I do not have to answer all of the written or interview questions. I understand that it will take me about two hours to answer the written questions and the interview questions.

Discomforts. The questions are not suppose to be difficult or disturbing to me. The only inconvenience is the time I will be giving up to be in the study.

Benetits. I understand that this study is not expected to help me, but what they learn from the study may help other young people and their families in West Virginia and other states.

Confidentiality. I have been promised that anything they learn about me in this study will be kept confidential. Any materials that I complete and my interview will be given an identification number, instead of my name. Only the research investigator, Dr. Carol Markstrom-Adams, and her assistants will know that I was in the study.

Voluntary Participation. I have been told that I do not have to be in this study. No one will be upset with me if I refuse to do this, or quit after I have started. I have been allowed to ask questions about the research, and all of my questions were answered. I will receive a copy of this form after I sign it.

I willingly agree to be in this study.

Signature of Participant Date

Signature of Investigator or Date

Investigator's Representative

304 293-3402 = FAx 293-2750 - 702 Allen mall = Po 30x 0124 - Murgantowni Wv 205006-6124 Equal Opportunity Aitirmative Action institution 
Appendix D

Adolescent Consent Form 


\section{CONSENT FORM}
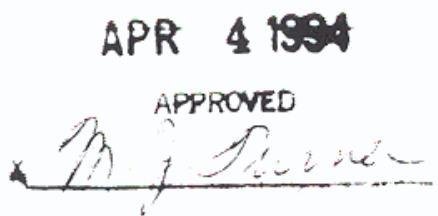

Social Processes. Coping, and Adjustment in Resilient Economically-Deprived Rural West Virginia Youth

Introduction. I. have been asked to be in this research study. which has been explained to me by a research assistant on this project. This research is being conducted by Dr. Carol Markstrom-Adams, Division of Family Resources, West Virginia University.

Purposes of the Study. I have been told that the purpose of this study is to learn more about rural high school students in West Virginia who might be facing difficulties related to poverty and making decisions about their plans after high school.

Description of Procedures. This study will be performed in my home, and involves my completion of written questions. The questions will be related to how I feel about myself, my family, and my marriage. I also will be interviewed and the interview will be audiotaped. I will be asked questions about goals that I would like to see my adolescent fulfil in his/her near future. I do not have to answer all of the written or interview questions. I understand that it will take me about two hours to answer the written questions and the interview questions.

Discomforts. The questions are not suppose to be difficult or disturbing to me. The only inconvenience is the time I will be giving up to be in the study.

Benefits. I understand that this study is not expected to help me, but what they learn from the study may help other young people and their families in West Virginia and other states.

Confidentiality. I understand that any information obtained as a result of my participation in this research will be kept as confidential as legally possible. I understand that these research records, just like hospital records, may be subpoenaed by court order or may be inspected by federal regulatory authorities. However, I also know that such an occurrence is highly unlikely given the nature of this research. In any publications that result from this research, neither my name nor that of my adolescent nor any information from which we might be identified will be published. Any materials that I complete and my interview will be given an identification number, instead of my name. Only the research investigator, Dr. Carol Markstrom-Adams, and her assistants will know that I was in the study.

Voluntary Participation. Participation in this study is voluntary. I understand that I may withdraw from this study at any time. Refusal to participate or withdrawal will involve no penalty or loss of benefits for me or my adolescent. I have been given the opportunity to ask questions about the research, and I have received answers concerning areas I did not understand. Upon signing this form, I will receive a copy. 
I willingly agree to be in this study.

Signature of Participant

Signature of Investigator or Investigator's Representative
Date

Date 
Appendix E

Home-Visit Checklist 


\section{Home-Visit Checklist \\ Year 2}

Did the teenager cumplete the following?

Y N

1. Assent forms (two copies, adolescent keeps one)

2. Background Information

3. Relationship with Family and Friends

4. Ways of Coping

5. EOM-EIS Self-Perception

6. Family Relationships

7. Feelings About Yourself

8. Interests and Activities

9. Perceived Life Chances Interview

10. Perceived Life Chances Questionnaire

11. Self-Assessment Questionnaire

12. Ethnic/Cultural Orientation

13. Behavior Questionnaire

14. Social Support Questionnaire

15. Relationship with Mother and Father

16. Self-Image Questionnaire

17. Sign name and SS\# on "money received" form

Did at least one parent complete the following?

Y N NA

1. Consent forms (two copies, parent keeps one)

2. Guardian consent forms (two copies, parent keeps one)

3. Release form (for school records)

4. Background Information

5. Family Relationships

6. Inventory of Parental Influence

7. Behavior Questionnaire

8. Behavior Problem Checklist

9. Aspirations for Teenager Interview

10. Developmental Interview

11. Family History

12. Sign their name and SS\# on "money received" form if teenager could not provide it

Did the interviewer/researcher do the following?

Y N NA

1. Read questions/directions to teenager if necessary

2. Read questions/directions to parent if necessary

3. Made sure both the parents and the teenager signed the school release form

3. Checked each side of each measure and made sure all questions were answered

4. Left a Business Reply envelope and the appropriate

5. Gave the participant $\$ 10$

forms/measures for the missing parent to use

6. Asked the African American adolescents for names and phone numbers of friends who may be interested in the study 
Appendix F

Parental Consent Form 


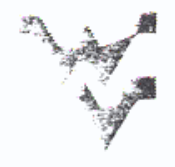

Division of Family Resources

West Virginia University

College of Agriculture ano forestry

PARENTAL OR GUARDIAN CONSENT FORM

Social Processes, Coping, and Adjustment in Resilient

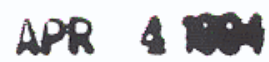

Economically-Deprived Rural West Virginia Youth

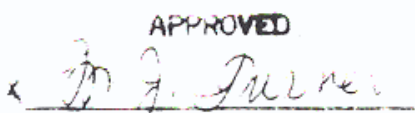

Introduction. 1 . have been asked to allow my adolescent to participate in this study. , who is serving

as a research assistant to Dr. Carol Markstrom-Adams at West Virginia University, has explained the study to me.

Purposes of the Study. I have been told that the purpose of this study is to learn more about rural high school students in West Virginia who might be facing difficulties related to poverty and making decisions about their plans after high school.

Description of Procedures. This study will be performed in my home. My adolescent will meet privately with the research assistant and be given several lists of written questions to answer. The questions will be related to feelings my adolescent has about him/herself, our family, and his/her life, in general. My adolescent will be interviewed on questions related to plans for his/her future, and the interview will be audiotaped. I understand that it will take about two hours to answer the written questions. I have been given an opportunity to examine these questionnaires and interview items. I agree to not examine my adolescent's responses to the questions, to protect his/her right to confidentiality.

Discomforts. The questions are not suppose to be difficult or disturbing to my adolescent. The only inconvenience is the time that will be given to be in the study.

Benefits. I understand that this study is not expected to help my adolescent personally, but what is learned from the study may help other young people and their families in West Virginia and other states.

Contact Persons. For more information about this research, I can contact at or her supervisor, Dr. Carol Markstrom-Adams at (304) 293-3402 ext. 775.

For information regarding my child's rights as a research subject, I may contact the Executive Secretary of the Institutional Review Board at (304) 293-7073.

Confidentiality. I understand that any information obtained as a result of my adolescent's participation in this research will be kept as confidential as legally possible. I understand that these research records, just like hospital records, may be subpoenaed by court order or may be inspected by federal regulatory authorities. However, I also know that such an occurrence is highly unlikely given the nature of this research. In any publications that result from this research, neither my name nor that of my adolescent nor any information from which we might be identified will be published.

304 293-3402 o FAX 293-2750 - 702 Allen Mali = PO B0x5124 = Morgantown ivy 20506-0124

Equal Opportunity Aftirmative Action Institution 
Voluntary Participation. Participation in this study is voluntary. I understand that I may withdraw my adolescent from this study at any time. Refusal to participate or withdrawal will involve no penalty or loss of benefits for me or my adolescent. I have been given the opportunity to ask questions about the research, and I have received answers concerning areas I did not understand. Upon signing this form. I will receive a copy.

I willingly consent to my adolescent's participation in this study.

Signature of Parent or Guardian Date

Signature of Investigator or

Date

Investigator`s Representative 
Appendix G

Perceived Life Chances Interview 
ID *

\section{Perceived Life Chances Interview - Year 2 \\ (given to teenager)}

Directions: Write the adolescent's response in the space provided. Begin with reading the following:

"In this interview we are interested in learning something about how kids see their future. Almost everyone spends some time thinking about what life will be like for then. please answer these questions about your own future as realistically and honestly as you can. If you don't understand something, be sure to ask me what it means."

1. What job would you like to have when you're finished with your education?

2. There are many things which wight keep a person from getting the job she/he would like to have. What are the things you feel might stand in the way of your getting this job?

3. a. Do you think you will get married at some time? (Read options and ask his/her response, then circle.)

Yes Ho Uncertain

b. If so, when would you like to get narried?

4. a. Do you think you will have children at some time?

Ies Ho Uncertain

b. If so, when would you like to have children? 
8. Let's talk about what your parents or the people who are raising you want you to do after high school. For each statement I read, tell me if you think they want you to do the activity right away, later on, or not at all.
a. Go to business or trade school, such as beauty school or computer training?
b. Go to college?
c. Get a job?
d. Get married?
e. Go into the service?

9. What sorts of things will you be doing after high school to make you feel like you are right on track in life (i.e. continue schooling, working, etc...)?

10. Think ahead to after you are finished with all of your schooling, what will your life be like to make you feel like you are making a success of things (i.e. good job, narried, ow home, etc...)?

Now I an going to give you a short questionnaire to complete with questions related to your future job. 
Appendix H

Inventory of Parental Influence 
ID\#

INVENTORY OF PARENTAL INFLUENCE (IPI) - YEAR 2

PART 1: AGREE/DISAGREE

FORM FOR MOTHER

Directions: For each of the statements below, please place a number on the line which corresponds best with your answer.

Rating Scale:

$1=$

Strongly

Disagree
$2=$

Disagree
$3=$

Uncertain
$4=$

Agree
$5=$

Strongly

Agree

1. The more self-disciplined a person is the more successful he/she will be in life.

2. I'm satisfied if I know my teenager does his/her best.

3. I have much patience with my teenager when it comes to his/her education.

4. I am enthusiastic about my teenager's education.

5. My teenager is smarter than he/she thinks.

6. My teenager does well in school mostly because of my help.

7. I think my teenager can do better in school than he/she does.

8. My teenager should only miss school when absolutely necessary.

9. I do not feel that my teenager is doing his/her best in school.

10. My teenager is afraid to come home with a poor grade.

11. I think my teenager doesn't get enough homework.

12. I help my teenager with school work only when asked.

13. I am never satisfied with my teenager's grades.

14. It is important to me that my teenager select friends from classmates who are the better students. 
Rating Scale:

(IPI cont.)

$\begin{array}{lllll}1= & 2= & 3= & 4= & 5= \\ \text { Strongly } & \text { Disagree } & \text { Uncertain } & \text { Agree } & \begin{array}{l}\text { Strongly } \\ \text { Agree }\end{array} \\ \text { Disagree } & & & & \end{array}$

15. I have doubts when my teenager says that he/she has no homework.

16. I want my teenager to go to a "good" university.

17. I will be very upset if my teenager doesn't make the top of the class.

18. I don't feel my teenager does his/her best in school.

19. School would be more pleasant for my teenager if I were not so strict.

20. I feel teenagers need parental guidance when it comes to schoolwork.

21. I am "pushy" when it comes to my teenager's education.

22. I expect my teenager to go to a university.

23. I am only pleased when my teenagers gets $100 \%$ on a test.

24. My teenager is basically lazy, and if it were not for me he/she would not be doing as well in school.

25. I take a big interest in my teenager's schoolwork.

26. I get along well with my teenager.

27. When my teenager needs help I hire a tutor.

28. I am proud of my teenager. 
Directions: For each of the statements below, please place a number in on the line which best corresponds with your answer.

Rating Scale:

$1=$

Never

\section{$2=$}

Rarely
$3=$

Sometimes

\section{$4=$}

Usually
$5=$

Always

29. I go over my teenager's mistakes when he/she brings home a test.

30. I encourage my teenager to read right before going to sleep.

31. I don't allow my teenager to go out and play until he/she finishes his/her homework.

32. I help with my teenager's math homework.

33. I encourage my teenager to go to the local library.

34. I keep track of the amount of time my teenager gives to homework.

35. I help my teenager with schoolwork he/she doesn't understand.

36. I help my teenager select books to read.

37. I check my teenager's homework.

38. I encourage my teenager to read books.

39. I help my teenager study before a test.

40. I set definite rules regarding the kinds of television programs my teenager can watch.

41. I insist that homework be completed each day. 
Rating scale:

(IPI cont.)

$\begin{array}{lllll}1= & 2= & 3= & 4= & 5= \\ \text { Never } & \text { Rarely } & \text { Sometimes } & \text { Usually } & \text { Always }\end{array}$

42. When my teenager watches too much TV I restrict his/her TV time.

43. I want my teenager to bring home test papers to see how well he/she did.

44. I help with my teenager's school reports.

45. I expect my teenager to do his/her homework at the same time each night.

46. Before leaving for school I ask if my teenager has everything needed (homework, books, reports).

47. I insist my teenager set aside a certain time for reading.

48. I encourage my teenager to spend more time in bookstores.

49. I supervise my teenager's homework.

50. I buy books for presents.

51. When my teenager is absent, I tell him/her to telephone a friend to get the homework.

52. I determine how much television my teenager can watch.

53. I insist that my teenager watch "educational" television programs.

54. We supply lots of reading material for my teenager. 
ID \#

INVENTORY OF PARENTAL INFLUENCE (IPI)- YEAR 2

FORM FOR FATHER

PART 1: AGREE/DISAGREE

Directions: For each of the statements below, please place a number on the line which corresponds best with your answer.

Rating Scale:

$1=$

Strongly

Disagree
$2=$

Disagree
$3=$

Uncertain
$4=$

Agree
$5=$ Strongly Agree

1. The more self-disciplined a person is the more successful he/she will be in life.

2. I'm satisfied if I know my teenager does his/her best.

3. I have much patience with my teenager when it comes to his/her education.

4. I am enthusiastic about my teenager's education.

5. My teenager is smarter than he/she thinks.

6. My teenager does well in school mostly because of my help.

7. I think my teenager can do better in school than he/she does.

8. My teenager should only miss school when absolutely necessary.

9. I do not feel that my teenager is dong his/her best in school.

10. My teenager is afraid to come home with a poor grade.

11. I think my teenager doesn't get enough homework.

12. I help my teenager with school work only when asked.

13. I am never satisfied with my teenager's grades.

14. It is important to me that my teenager select friends from classmates who are the better students. 
Rating Scale:

(IPI cont.)

$1=$

Strongly

Disagree $2=\quad 3=$

Disagree
Uncertain
$4=$

Agree
$5=$

Strongly

Agree

15. I have doubts when my teenager says that he/she has no homework.

16. I want my teenager to go to a "good" university.

17. I will be very upset if my teenager doesn't make the top of the class.

18. I don't feel my teenager does his/her best in school.

19. School would be more pleasant for my teenager if I were not so strict.

20. I feel teenagers need parental guidance when it comes to schoolwork.

21. I am "pushy" when it comes to my teenager's education.

22. I expect my teenager to go to a university.

23. I am only pleased when my teenagers gets $100 \%$ on a test.

24. My teenager is basically lazy, and if it were not for me he/she would not be doing as well in school.

25. I take a big interest in my teenager's schoolwork.

26. I get along well with my teenager.

27. When my teenager needs help I hire a tutor.

28. I am proud of my teenager. 
PART 2: FREQUENCIES

(IPI cont.)

Directions: For each of the statements below, please place a number in on the line which best corresponds with your answer.

Rating Scale:

$1=$

Never

$2=$

Rarely
$3=$

Sometimes
$4=$

Usually
$5=$

Always

29. I go over my teenager's mistakes when he/she brings home a test.

30. I encourage my teenager to read right before going to sleep.

31. I don't allow my teenager to go out and play until he/she finishes his/her homework.

32. I help with my teenager's math homework.

33. I encourage my teenager to go to the local library.

34. I keep track of the amount of time my teenager gives to homework.

35. I help my teenager with schoolwork he/she doesn't understand.

36. I help my teenager select books to read.

37. I check my teenager's homework.

38. I encourage my teenager to read books.

39. I help my teenager study before a test.

40. I set definite rules regarding the kinds of television programs my teenager can watch.

41. I insist that homework be completed each day. 
Rating Scale:

(IPI cont.)

$\begin{array}{lllll}1= & 2= & 3= & 4= & 5= \\ \text { Never } & \text { Rarely } & \text { Sometimes } & \text { Usually } & \text { Always }\end{array}$

42. When my teenager watches too much TV I restrict his/her TV time.

43. I want my teenager to bring home test papers to see how well he/she did.

44. I help with my teenager's school reports.

45. I expect my teenager to do his/her homework at the same time each night.

46. Before leaving for school I ask if my teenager has everything needed (homework, books, reports).

47. I insist my teenager set aside a certain time for reading.

48. I encourage my teenager to spend more time in bookstores.

49. I supervise my teenager's homework.

50. I buy books for presents.

51. When my teenager is absent, I tell him/her to telephone a friend to get the homework.

52. I determine how much television my teenager can watch.

53. I insist that my teenager watch "educational" television programs.

54. We supply lots of reading material for my teenager. 


\author{
208 Stonegate Circle \\ Morgantown, WV 26505 \\ (304) 598-5929
}

\title{
ACCOMPLISHMENTS/EXPERIENCES
}

Accomplishments include six years experience with children from $\mathrm{K}-5$ in an elementary setting... An internship at a Regional Correctional Facility that provided the opportunity to work with diverse families in a challenging setting... Various leadership abilities illustrated as chairperson of School Leadership Team ... Instructed and organized events for children from ages 5-15 at several basketball camps... Majority of college expenses paid via athletic scholarship and summer work.

\section{EDUCATION}

Shepherd College, Shepherdstown, WV

B.A. Elementary Education, Endorsement - Early Childhood

Education, December 1993

GPA: 3.0

Master's degree in Child Development/Family Studies to be completed $5 / 2000$ at West Virginia University.

\section{WORK EXPERIENCE}

\section{August 1998-Present}

Graduate Assistantship, West Virginia University, Morgantown, WV

- Responsibilities include research and data collection.

Internship, Kennedy Center Regional Correctional Facility, Morgantown, WV

- Responsibilities included interacting with children of incarcerated fathers, preparing various lesson plans, and instruction of inmate parenting classes.

August 1997-May 1998

Admissions Counselor, Shepherd College, Shepherdstown, WV

- Actively recruited high school students to attend college.

- Participated in organized college fairs and made individual high school visits.

January 1994-June 1997

Elementary Teacher, Boyce Elementary School, Boyce, VA

$2^{\text {nd }}$ Grade, January to June 1994 
$1^{\text {It }}$ Grade, September 1994 - June 1997

Chairman of School Leadership Team, 1996-1997

Co-Chairman of School Leadership Team, 1995-1996

Chairman of High Expectations Committee, 1994-1995

Participated in Quality Training Process Workshop, 1994

- As Chairperson of the School Leadership Team, my responsibility was to develop, promote and implement improvement opportunities within the school.

In addition my teaching responsibility included several "home visits" to my students' homes. This enhanced communication between teacher and caregiver.

\section{Summer of 1992-1994}

National Youth Sports Program, Camp Counselor, Shepherdstown, WV

- Supervised thirty (30) disadvantaged female and male students (ages 10-14) and was responsible for teaching responsibility and teamwork through participation in various athletic activities.

\section{Summer of 1995-1999}

Basketball Camp Commissioner/Counselor, Potomac, MD

Assistant Director, July 1999, Baltimore, MD

- Responsible for organizing daily events and instructing fundamental skills.

\section{OTHER ACTIVITIES}

Clarke County High School, Berryville, VA

- Head Basketball Coach, Junior Varsity: Assistant Coach, Varsity, 1996-1997

Johnson-Williams Middle School, Berryville, VA

- $8^{\text {th }}$ Grade Basketball Coach, 1995-1996

\section{RELATED ACTIVITIES}

Gamma Sigma Delta

Recipient, Dean's List

Shepherd College Varsity Basketball, 1989-1993: Named Team Captain, 1992-1993

National Council on Family Relations - 1998-99

Active Member - St. John's Church - Morgantown, WV

\section{REFERENCES PROVIDED UPON REQUEST}

